\title{
A review of lifestyle and environment risk factors for pancreatic cancer.
}

ZANINI, S., RENZI, S., LIMONGI, A.R., BELLAVITE, P., GIOVINAZZO, F. and BERMANO, G. 
1 A review of lifestyle and environment risk factors for pancreatic cancer

2

3 Sara Zanini ${ }^{1}$, Serena Renzi ${ }^{1}$, Antonina Rita Limongi ${ }^{2,3}$, Paolo Bellavite ${ }^{4}$, Francesco Giovinazzo ${ }^{5 *}$,

4 Giovanna Bermano ${ }^{1 * \#}$

$5 \quad{ }^{1}$ Centre for Obesity Research and Education [CORE], School of Pharmacy \& Life Sciences, Robert

6 Gordon University, Aberdeen, UK

$7 \quad{ }^{2}$ Department of Science, University of Basilicata, Potenza, Italy

$8 \quad{ }^{3}$ BioInnova Srl, Potenza, Italy

$9 \quad{ }^{4}$ Department of Medicine, Section of General Pathology, University of Verona, Italy

$10{ }^{5}$ Policlinico A. Gemelli, Liver Transplant Unit, Roma Italy

$11 *$ These authors equally contributed to the manuscript

12 \# corresponding author

13 Corresponding author:

14 Dr Giovanna Bermano

15 Centre for Obesity Research and Education (CORE)

16 School of Pharmacy \& Life Sciences

17 Robert Gordon University

18 Aberdeen, AB10 7GJ, UK

19 Email: g.bermano@,rgu.ac.uk

Tel: +441224262885 
22 Highlights

23 - Smoking, high alcohol and red meat intake increase PaCa risk.

24 - Obesity and diabetes stimulate insulin production and predispose to onset of $\mathrm{PaCa}$

25

- Lifestyle and behaviour are linked with $\mathrm{PaCa}$ by plausible biological processes

26

- Inflammation a potential common mechanism to lifestyle environment, diseases \& $\mathrm{PaCa}$ 
Abstract

29

Pancreatic cancer $(\mathrm{PaCa})$ is one of the most deadly cancers known and its incidence is increasing in developed countries. Because of the lack of biomarkers that allow early detection and the tendency of the disease to be asymptomatic, the diagnosis comes often too late for effective surgical or chemotherapy intervention.

Lifestyle factors, that may cause common genetic modifications occurring in the disease, interfere with pancreatic physiology or function, and play a role in $\mathrm{PaCa}$ development, have been of concern recently, since a strategy to prevent this severe cancer is needed. This review identifies the latest evidences related to increased risk of developing PaCa due to dietary habits such as high alcohol, fructose and red or processed meat intake, and pathological conditions such as diabetes, obesity and infections in addition to stress and smoking behavior. It aims to highlight the importance of intervening on modifiable risk factors: the action on these factors could prevent a considerable number of new cases of $\mathrm{PaCa}$.

Keywords: Pancreatic cancer, life style factors, tobacco smoking, alcohol intake, sugar and fructose intake, red and processed meat, environmental and synthetic toxins, obesity, type 2 diabetes, metabolic syndrome, infectious diseases, psychological stress. 


\section{INTRODUCTION}

Pancreatic Cancer $(\mathrm{PaCa})$ is one of the most lethal diseases with a 5-year survival rate of about $8 \%$ and a survival rate after the first year of diagnosis of $20 \%$ [1]. According to last statistics, overall cancer incidence and mortality rates have both declined when considering the total American population [1] and, in the United Kingdom (UK), the number of deaths due to cancer is decreased by about $9 \%$ in the last ten years [2]. Despite this tendency, pancreatic carcinoma, along with liver, soft tissues and uterus cancer, represents an exception showing an increase, rather than a decrease, in both incidence and mortality rate of $0.3 \%$ for men and $0.4 \%$ for women per year in the United States [3]. During the last decade, PaCa mortality rates in the UK population have increased by $6 \%$, whereas the incidence rate increased by $9 \%$ and $11 \%$ in men and women respectively. In 2015 , this cancer represented $3 \%$ of all new cases with no heterogeneity between male and female [2]. Incidence increases with age: $\mathrm{PaCa}$ is rare in people under 25 years of age, still relatively uncommon for those under 40 , while $80 \%$ of the cases are diagnosed in people between 60 and 80 [4]. Only after 80 years of age, a decrease in incidence in both sexes can be observed [1]. Epidemiological studies show that people of African American and Jewish descent have a higher incidence rate of $\mathrm{PaCa}$ than Caucasians; the incidence of $\mathrm{PaCa}$ is higher among men compared with women and positive clinical outcome is lower in people with a low socioeconomic status [5-9]. Ninety-five percentage of $\mathrm{PaCa}$ arises from ductal epithelial cells through a well-defined sequence of events from pancreatic intraepithelial neoplasia (PanIN) to invasiveness carcinoma and metastasis or pre-malignant lesions of the pancreas as intraductal papillary mucinous neoplasm (IPMNs) and mucinous cystic neoplasm (MCNs) [8]. Some of the most characterised genes whose mutations have been recognized in the pathogenesis of $\mathrm{PaCa}$ are the tumour suppressor genes CDKN2A (cyclin-dependent kinase inhibitor 2A), SMAD4, TP53 (Tumor Protein P53) and the KRAS oncogene [10].

To date acting on preventable risks is a way that should be pursued considering the lack of screening programs and effective therapeutic options [11, 12]. It has been estimated that about $37 \%$ 
of new cases could be preventable [2]. The report on PaCa that was built together in 2012 under the Continuous Update project by the World Cancer Research Fund International (WCRF) [13] and the American Institute for Cancer Research listed several factors connected with lifestyle that could play a promoting or protective activity on the risk to develop $\mathrm{PaCa}$ [13]. Established risk factors, such as cigarette smoking, alcohol intake, consumption of red and processed meat and high fructose drinks have been the subject of consideration since long but other predisposing factors such as obesity and sedentary life are powerfully emerging. It has been predicted that obesity will overtake smoking as the biggest environmental risk factor for PaCa. World health organisation (WHO) data predict an increasing incidence to nearly 12,000 cases per annum by 2030 : current incidence being 8,880 , an increase of $35 \%$ in 14 years [14]. Therefore, the present review summarises the evidence of a relationship between lifestyle, environmental factors and diseases, and increased risk to develop PaCa focusing mainly on the underlying biological/molecular mechanisms.

\section{Lifestyle and Environmental Risk Factors}

\section{Tobacco smoking}

Tobacco smoking represents the first investigated modifiable risk factor for PaCa development, and, contrary to other environmental factors, the literature agrees worldwide that a significant elevated risk has been identified in current smokers compared with never smokers (odds ratio (OR) 1/4 1.77, 95\% CI: $1.38,2.26)[15]$, and the liability of smoking to PaCa development has been estimated to be about $15-20 \%[15,16]$. A large meta-analysis, including 254 studies, showed that current smokers, in addition to have a remarkably higher risk of developing respiratory tract cancers (lung relative risk $(\mathrm{RR})=8.96 ; 95 \%$ confidence interval $(\mathrm{CI}): 6.73-12.11$; laryngeal $\mathrm{RR}=6.98 ; 95 \% \mathrm{CI}$ : 3.14-15.52; pharyngeal $R R=6.76 ; 95 \% \mathrm{CI}: 2.86-15.98)$, also have high $\mathrm{RR}$ for $\mathrm{PaCa}(\mathrm{RR}=1.70$; 95\% CI: 1.51-1.91) [17]. These findings have been supported by a more recent meta-analysis that estimated an increase of $48 \% \mathrm{RR}$ of $\mathrm{PaCa}$ development in ever smokers compared to never-smokers and an excess of risk of $82 \%$ and $17 \%$ in current and former smokers, respectively [18]. According 
to a large cohort study, the population attributable risk (PAR) for smoking (calculated on current smokers and smoking cessation for $<10$ years) in PaCa was of $14 \%$, compared with other 4 risk factors (alcohol use 3\%, dietary quality 3\%, body mass index (BMI) $8 \%$ and physical activity $3 \%$ ) [19].

Smoking behaviors also influence the survival of diagnosed patients: habitual smokers have a higher risk to develop multiple primary malignancies compared to non-smokers; patients that continue to smoke, develop new malignancies earlier than patients that stopped smoking after the first diagnoses of cancer (6.11 vs 11.5 years, respectively) [20]; and smokers have a 7\% increase of risk for each cigarette smoked per day as estimated from dose response analysis [17]. The duration and intensity of smoking were found to be related as well: the first is responsible for an increased risk of $1 \%$ for each year of smoking and of $16 \%$ for a total duration of smoking of 10 years, whereas an increase of $2 \%$ in risk was observed for every cigarette per day [16, 21]. A metaanalysis conducted on 42 observational studies (30 retrospective and 12 prospective) pointed out the existence of a non-linear dose-response association between cigarette smoking and PaCa risk: it markedly increased for moderate consumption ( $17 \%$ for $5-25$ cigarettes per day) until it stabilized for a high intensity of consume ( $6 \%$ for $30-40$ cigarettes/day) [22]. Similarly the duration of smoking was found to be related in a non-linear manner with increase of $\mathrm{PaCa}$ risk, in fact, after 10 years of smoking RR was 1.3 (95\% CI: 1.3e 1.4), while RR of 1.7 (95\% CI: $1.5 \mathrm{e} 1.8)$ was observed after 20 years and 1.8 (95\% CI: 1.6e2.0) after 30 years of smoking. Interestingly, the risk of PaCa development decreased consistently with the increase of the years since stopping smoking. The same risk of non-smokers ( $0.6 \mathrm{RR}$ : 0.6 ; $95 \% \mathrm{CI}$ : $0.5 \mathrm{e} 0.6$ for never vs. current smokers) was reached after 20 years of stopping [18]. Dose-response relationship between duration and intensity of smoking, and increased death for PaCa was observed in a meta-analysis comprising 20 studies and 2,517,623 participants. PaCa total mortality risk was found to increase by $56 \%$ in current smokers and by $15 \%$ in former smokers [23]. Furthermore, a link between cigarette smoking and decrease of survival rate was observed among $\mathrm{PaCa}$ patients $(\mathrm{P}$ trend $=0.008)$, with hazard ratio $(\mathrm{HR})$ for death 
of $1.49(95 \%$ CI, 1.05 to 2.10$)$ for $>60$ pack-years when comparing smokers versus never smokers [24]. Differently from active smoking, passive exposure, referred as environmental tobacco smoke (ETS), is not indisputably linked to increased PaCa risk. In fact, Zhou et al in a meta-analysis including 10 studies did not found any significant association between $\mathrm{PaCa}$ incidence in nonsmokers and ETS exposure [25].

Although cigarette smoking has been considered as one unique risk factor, smokers are exposed to a mixture of different carcinogenic and toxic compounds, both organic and inorganic, such as polycyclic aromatic hydrocarbons, heterocyclic aromatic amines, metals, and even radioactive gas. For this reason, cigarette smoking could act through several different mechanisms in $\mathrm{PaCa}$ development [21]. N-nitrosamines such as N0-nitrosonornicotine (NNN), 4-[methylnitrosamino]-1[3-pyridyl]-1-butanone (NNK) are widely studied. The latter and its metabolite 4[methylnitrosamino]-1-[3-pyridyl]-1-butanol (NNAL) are considered the most important carcinogens in tobacco as they have been shown to cause PaCa in animal models [26]. They lead to KRAS mutation, the most common mutation that occurs in PaCa progression [27]. In mice, nicotine promotes carcinogenesis-inducing dedifferentiation of acinar cells through downregulation of GATA6 (GATA-binding factor 6) and subsequent hyperactivation of K-Ras [28]. Furthermore, NNK can exert an epigenetic effect on pancreatic cells, binding $\beta$-adrenergic receptors and causing the release of arachidonic acid (AA). AA metabolites exert a mitogenic effect activating cell proliferation and $\mathrm{PaCa}$ development in cancers that do not harbour KRAS mutations [27].

\section{Alcohol intake}

A large meta-analysis on 11 cohort studies and 21 case-control studies showed a strong association between $\mathrm{PaCa}$ development and heavy alcohol intake ( $>3$ drinks/day or $\geq 40 \mathrm{~g} / \mathrm{d}$ for dose/risk analysis) with an increase of $20 \%$ in PaCa risk, but no association was observed among non- or occasional drinkers ( $<3$ drinks/day). This positive association has been identified to be stronger in cohort studies compared to case-control studies [29]. In the context of the European Prospective 
Investigation into Cancer and Nutrition (EPIC) study, considering 1,238 incident cases, alcohol intake was positively found associated with $\mathrm{PaCa}$ risk in men, especially in heavy drinkers ( $>60$ $\mathrm{g}$ /day). Moreover, the intake of beer and liquor showed a stronger risk than wine consumption, whereas smoking status seemed not to affect the alcohol contribution in cancer [30]. Accordingly, Wang et al. confirmed the correlation between high alcohol intake (in particular liquor consumption) and $\mathrm{PaCa}$ incidence at a lower dose $(15 \mathrm{~g} / \mathrm{d})$ while Rosato et al. attributed $13 \%$ of $\mathrm{PaCa}$ cases in North Italy to heavy alcohol intake $[31,32]$. This non-linear relation could be due to bias linked with the method of analysis, such as limited number of reported cases, the contemporary exposure to different risk factors and the difficulty in adjusting for them such as tobacco smoking. Alcohol, indeed, might amplify the negative effects of tobacco smoking and other risk factors involved in PaCa development [21].

A possible suggested mechanism that could link alcohol intake and $\mathrm{PaCa}$ development has been identified into the metabolites of ethanol such as acetaldehyde that are released into the bloodstream. Acetaldehyde is able to bind DNA repair proteins, give rise to DNA damage and cause the formation of DNA adducts promoting tumorigenesis [33]. In addition, the metabolites of ethanol produced by the non-oxidative pathway (fatty acid ethyl esters) cause a sustained elevation of calcium released from intracellular stores [34]. The marked increase of calcium mediates toxicity in pancreatic acinar cells initiating the process of pancreatic auto-digestion, caused by premature trypsinogen activation [35]. Recurrent injuries to pancreatic acinar cells impair autophagy, which is a process aimed at limiting the extension of inflammation and damage to healthy cells that prevent neoplastic transformation [36].

\section{Sugar intake and fructose rich drinks}

In order to understand the role of sugar intake on $\mathrm{PaCa}$ incidence, several studies have been conducted. The attention has been focused on added sugar present in beverages such as corn derived high fructose syrups, not only because its consumption has increased in the last fifty years [37], but 
also because fructose from beverages is rapidly metabolized compared to the one present in solid foods [38].

A prospective analysis on 131 cases of $\mathrm{PaCa}$ showed a greater risk among big consumers of soft drink ( $>2$ /day) and sweetened fruit soups compared with sporadic consumers [39]. Similarly, in two additional cohort studies, an increased risk of $\mathrm{PaCa}$ was found among women (overweight and not) with high consumption of sugar-sweetened soft drinks, but not in men [40]. An association was also found when considering the intake of high free glucose and free fructose from fruit and fruit juice [41]: a meta-analysis conducted in 2012 showed that the fructose intake of $25 \mathrm{~g}$ /day was positively associated with a higher risk $\mathrm{RR}=1.22(95 \% \mathrm{CI}: 1.08-1.37, \mathrm{I} 2=0 \%)$ while no association was found between PaCa risk and respectively glycemic index, sucrose and high carbohydrates consumption [42]. These results could be explained by the important differences in sugars' type and their peculiarities in absorption. Despite fructose and glucose being chemically very similar, they are metabolized differently [43]: while glucose uses Na-dependent transporter, fructose is absorbed by glucose transporter type 5 (GLUT5) at the level of the small intestine and metabolized principally in the liver. Pancreatic $\beta$-cells produce insulin in response to high level of glucose in bloodstream causing the increase in transporters such as glucose transporter type 4 (GLUT4), used by glucose, and the store of this as glycogen, whereas GLUT5 is not responsive to this hormone and the uptake of fructose remain unregulated [43]. This behavior specific to fructose promotes pyruvate decarboxylation causing Acetyl-CoA synthesis, involved in de novo lipogenesis, and the consequent diacylglycerol (DAGs) accumulation can cause protein kinase-C (PKC) activation interfering with insulin signaling pathway leading to insulin resistance [44]. Furthermore, it has been demonstrated that fructose is preferentially used by PaCa cells compared with glucose in the non-oxidative Pentose Phosphate Pathway (PPP) that leads the 5-carbon pentose production from 6-carbon glucose, giving new substrates for RNA synthesis. Fructose is able to induces higher transketolase (TK) expression causing a faster use of both, fructose and glucose, via 
PPP [45]. The greater contribution of fructose to nucleic acid synthesis leads to the increase in uric acid production, resulting to purine metabolism [42].

Hsieh et al. carried out a study, using in vitro and in vivo models, to clarify the effective role of

204 fructose in PaCa development. High levels of this sugar have been shown to promote aggressive cancer development in mice and specific KRAS mutations when compared with normal diet fed mice, characterized by a higher grade of panIN lesions, and development of neoplastic lesions with higher level of GLUT5, ATP-binding cassette transporter ABCG2, $\beta$-galactoside $\alpha 2,6$ sialyltransferase 1 (ST6gal1) and with a higher metastatic power. In in vitro model, the substitution of glucose with fructose promoted the selectively outgrowth of invasive and drug resistant subpopulation of ABCG2-positive cells, and increased 2, 6 sialylation caused by upregulation of ST6gall involved in increased cancer cells metastatic potency [45].

\section{Processed and red meat intake}

214 Different studies have shown that a high intake of meat positively correlates with the risk of developing $\mathrm{PaCa}$. A meta-analysis conducted in 2012 on 11 prospective cohort studies showed a positive association between red and processed meat consumption and $\mathrm{PaCa}$ risk [46]. In the multiethnic large prospective cohort study conducted in Hawaii and Los Angeles, 215,000 men and women aged 45-75, belonging to the main cultural groups residing there (African-American, Latino, Japanese-American, Native Hawaiian and Caucasian), were enrolled between 1993 and 1996 and the associations with risk of $\mathrm{PaCa}$ development, based on different dietary habits, were investigated. After 7-years follow up, data on 190,545 patients were finally available. Four hundred and eighty two incidental PaCa cases were reported. The analysis showed that the intake of processed meat and red meat was strongly linked to an increased risk in developing $\mathrm{PaCa}(68 \%$ increased risk for the subjects in fifth quintile of meat daily intake $(18 \mathrm{~g} / 1000 \mathrm{kcal})$ compared with those in the lowest quintile $(2 \mathrm{~g} / 1000 \mathrm{kcal}) ; \mathrm{RR}=1.68,95 \% \mathrm{CI}=1.35$ to $2.07 ; \mathrm{p}$ trend $<0.01)$ and a positive trend with nitrosamine intake, derived by cooking on a grill, was observed $(p=n s)$ [47]. In 
2013, the associations between $\mathrm{PaCa}$ and meat and fish consumption were investigated in the EPIC study. No significant correlation was found between the consumption of red and processed meat 229 and an increase risk to develop PaCa [48].

230 There are several biological mechanisms that could connect $\mathrm{PaCa}$ development and the intake of red or processed meat. Cooking meat, especially at high temperatures, is responsible for the release of polycyclic aromatic hydrocarbons (PHAs) and heterocyclic amines (HCAs) that cause DNAdamage. N-nitroso compounds (NOC), formed in the preserving process, can cause the formation of DNA-adducts, although tobacco smoking is known to expose to higher concentration of these compounds [49]. Recently also the presence of heme iron in red meat has been hypothesized to play a causal role being a promoting agent of oxidative stress [50]. Taking altogether the association between red and processed meat consumption and $\mathrm{PaCa}$ development appears weak and in need of further studies but it cannot be excluded.

\section{Environmental and synthetic toxins}

241 Among exogenous environmental factors, Bis[2-ethylhexyl]phthalate (DEHP) has been linked with an elevated risk of PaCa [51]. DEHP is widely used as plasticizers for PVC (polyvinyl chloride) and, as a consequence, is present in many products such as floor and wall coverings, car interiors, nuclear receptors expression [54].

Exposure to cadmium has also been linked with an increased risk of PaCa. Cadmium is a toxic metal generated by the smelting of zinc, lead or copper ores. It is commonly used in battery production and is present in phosphate fertilizers and sewage sludge. It is mostly found in food (e.g. leafy vegetables, farinaceous products, shellfish), which represents the main source of exposure in 
the non-smoking population [55]. Interestingly, in south Louisiana, where a high rate of $\mathrm{PaCa}$ is registered, dust specimens collected from 315 indoor and outdoor samples revealed that 64 of them exceeded the Environmental Protection Agency's guidelines for cadmium, likely due to the industrial activity that contaminated much of the wetlands in Louisiana $[56,57]$. An increase in urinary cadmium concentrations was found to be significantly associated with an increased risk of $\mathrm{PaCa}\left(2^{\text {nd }}\right.$ quartile $\mathrm{OR}=3.34,3^{\text {rd }}=5.58,4^{\text {th }}=7.70$; test for trend $\left.\mathrm{p}<0.0001\right)$ [58]. Because of the mechanism of molecular mimicry, cadmium interferes with zinc-mediated processes binding to metallothioneins, especially in the liver and kidney [55]. Accordingly, a study conducted in 2016 showed that chronic exposure to low levels of cadmium lead to the expression of special AT-rich sequence-binding protein 2 (SATB2), a transcription factor, physiologically not expressed in normal human pancreatic cells but expressed in cancer stem cells and pancreatic cancer cell lines.

The induction of SATB2 expression may represent one of the mechanisms involved in cell transformation [59].

Further evidences are provided by a study focused on 12 trace elements found in toenail samples. The research confirmed the link between $\mathrm{PaCa}$ and the exposure to arsenic and cadmium and reported a novel association with lead [60]. Another toenail sample-based study investigated the relation between the amount of trace elements and occupational history. Exposure to organic solvents, pesticide and volatile sulphur compounds showed a higher concentration of different metals. In particular, in presence of a pesticide exposure, cadmium levels were $0.056 \mu \mathrm{g} / \mathrm{g}(95 \% \mathrm{CI}$ 0.029-0.108), whereas, for unexposed cases, was only $0.023 \mu \mathrm{g} / \mathrm{g}(95 \% \mathrm{CI} 0.017-0.031)$ [61]. In 2013, a large epidemiological study including 3,932 people confirmed a correlation between arsenic exposure and $\mathrm{PaCa}$ with a hazard ratio of 2.46 (1.09-5.58) [62]. In addition, an ecological cancer mortality study on 7,917 Spanish towns highlighted an association between arsenic topsoil concentration and $\mathrm{PaCa}$ mortality [63]. On the other hand, an inversely association between $\mathrm{PaCa}$ risk and high selenium and nickel concentrations was found even if the inversely association with nickel remains highly controversial in the literature. Selenium can exert a protective effect against 
oxidative stress induced by other elements or boost the activity of proteins involved in DNA repairing or apoptosis [60].

A clinic-based case-control study showed an increased risk of $\mathrm{PaCa}$ caused by the regular exposure also to other chemicals such as benzene, asbestos and chlorinated hydrocarbons whereas chromium and nickel were not significantly associated [64]. A moderate increment in K-Ras activation has been observed analyzing the samples of pancreatic tumors collected by patient subjected to occupational exposure to metals such as lead, nickel and chromium and to different chemicals such as polycyclic aromatic hydrocarbons (PAHs), gasoline and benzo[a]pyrene [65].

\section{Multifactorial Risk Factors}

\section{Obesity}

Obesity, defined as a BMI equal or higher than $30 \mathrm{~kg} / \mathrm{m}^{2}$, has long been recognized as a risk factor for a variety of pathological conditions such as diabetes mellitus, hypertension, dyslipidaemia, ischemic heart disease and some types of cancer such as breast, endometrium, oesophagus, colon, kidney and pancreas $[66,67]$. Central adiposity, measured as waist to hip ratio (WHR), is more strongly related to insulin resistance and diabetes, two recognized PaCa risk factors [68]. In 2007, WCRF reported that there are increasing and convincing evidences that obesity is linked with a higher risk of developing $\mathrm{PaCa}[13]$.

A case control study, involving 841 pancreatic adenocarcinoma patients and 754 controls, highlighted the relationship between overweight (BMI $25-29.9 \mathrm{~kg} / \mathrm{m}^{2}$ at $14-39$ years), obesity (BMI $>30 \mathrm{~kg} / \mathrm{m}^{2}$ at $20-49$ years) in early adulthood and an increased risk of $\mathrm{PaCa}(\mathrm{OR}, 1.67 ; 95 \% \mathrm{CI}$, 1.20-2.34 and OR, 2.58; 95\% CI, 1.70-3.90, respectively) [69]. Moreover, a pooled analysis on 14 cohort studies was conducted to evaluate the association between obesity and anthropometric factors (BMI at younger ages, waist circumference, hip circumference or WHR), and PaCa risk distinguishing between men and women because of the different hormonal status and lifestyle factors that could affect the study [70]. A positive association between obese people and PaCa risk was found (increased by $47 \%, 95 \% \mathrm{CI}=23-75 \%$ ) with the female and male groups showing similar 
risk. PaCa risk was higher $(54 \%, 95 \% \mathrm{CI}=24-93 \%)$ for those who were overweight in early adulthood and obese at baseline, and 40\% higher for those who gained weight (BMI $\geq 10 \mathrm{~kg} / \mathrm{m}^{2}$ between baseline time and younger ages compared to individuals who remained stable). Considering WHR and comparing the highest versus lowest quartile, a 35\% greater risk was observed $(p=n s)$ [70]. An analysis conducted on pooling data from nested case-control studies from the NCI PaCa Cohort Consortium (PanScan), which included 2,170 cases and 2,209 controls, showed a positive association between increasing BMI and risk of $\mathrm{PaCa}$ for all subjects (adjusted OR for the highest vs. lowest BMI quartile $\left.=1.33,95 \% \mathrm{CI}=1.12-1.58, \mathrm{p}_{\text {trend }}<0.001\right)[71]$. A pooled analysis of nine Japanese cohort studies, reveled an increased risk of PaCa among obese men ( $\geq 30 \mathrm{~kg} / \mathrm{m}^{2}$ compared with 23 to $<25 \mathrm{~kg} / \mathrm{m}^{2}$, adjusted HR $1.71 ; 95 \%$ CI, 1.03-2.86), whereas the risk among women was not clear [72]. However, recent studies have demonstrated that a loss of weight reduced the risk of $\mathrm{PaCa}$ development in overweight or obese postmenopausal women [73]. In the EPIC study, Kliemann et al. predicted and associated basal metabolic rate (BMR) to risk for different cancer types. Interestingly, BMR was found positively associated with $\mathrm{PaCa}$ risk $\left(\mathrm{HR}_{1-\mathrm{sd}}\right.$ : 1.37; 95\%CI 1.13 - 1.66) also in normal-weight persons $\left(\mathrm{BMI}<25 \mathrm{~kg} / \mathrm{m}^{2}\right)[74]$.

\section{Type 2 Diabetes}

Obesity is a recognized cause of type 2 diabetes (T2D), one of the major established causes of PaCa itself: about $80 \%$ of T2D patients are overweight or obese. Both T2D and obesity are characterized by a pro-inflammatory state, having insulin resistance as common results. The adipose tissue is able to secrete several molecules known as adipokines, including hormones regulating energy homeostasis, cytokines with anti- and pro-inflammatory action and peptides involved in glucose homeostasis [75]. In addition, oxidative stress induced by high intake of glucose and macronutrients intake and the consequent increase in the production of pro-inflammatory cytokines, such as tumour necrosis factor alpha (TNF- $\alpha$ )-and interleukine-6 (IL-6), can interfere with the signal transduction of insulin, leading to insulin resistance [76]. Concerning the NIH-AARP Diet and Health Study 
(AARP), Zheng et al. used a dietary inflammatory index (DII $\left.{ }^{\circledR}\right)$ score to evaluate pancreatic cancer risk. They examined also the effect that modification by inflammation-related lifestyle factors would induce: no significant association was, however, detected in relation to PaCa risk [77]. Increasing and strong evidences related to the association between $\mathrm{T} 2 \mathrm{D}$ and $\mathrm{PaCa}$ development are available. In a meta-analysis on 35 cohort studies, patients with diabetes showed a doubled risk to developing $\mathrm{PaCa}$ and Huxley's meta-analysis pointed out that individuals with long-standing diabetes have still a 50\% RR more than individuals without diabetes even if a negative relationship was found with duration of diabetes $[78,79]$. On the other hand, Magruder et al. reported that a 4-7fold risk of $\mathrm{PaCa}$ is present also in recent onset diabetes [80], and positive relationship has been found between fasting glucose level and cancer risk in a cohort analysis of 1,298,385 Korean people [81]. It is, however, important to underline that studies on long standing diabetes are more likely to have biases due to self-reported illness.

The recent PanGenEU study has explored the different associations between PaCa risk and T2D subtypes evaluating also the interplay of obesity. Individuals with T2D compared with non-T2D showed an increased PaCa risk, and among diabetics, the ones with new-onset T2D had a higher risk. However, data suggest that, in the latter group, emerging diabetes may result as a consequence of cancer cell growth, whereas, in long-standing T2D, diabetes may represent a mediator within the pathway that leads from obesity to cancer [82]. Butler et al. found that replication of pancreatic cells duct was increased 10 folds in patients with T2D compared with lean nondiabetics: patients with both $\mathrm{PaCa}$ and T2D had enlarged ducts and hypertension and increased tumour size [83]. PaCa patients diagnosed with diabetes lasting five or more years showed a positive association with KRAS codon 12 mutations [84]. Recently, a study meant to investigate the role of diabetes in influencing pancreatic tumour immune microenvironment, highlighted the higher inflammatory status, due to high level of macrophage and lymphocyte infiltration, phenomenon associated with a poorer survival [85]. 
Interestingly, cancer risk associated with diabetes can also be influenced by antidiabetic therapy. A retrospective cohort study based on the population resident in the Saskatchewan province (around 1 million) found that, in a cohort of 10,309 people that used antidiabetic drugs for more than 1 year, people had a greater cancer-related mortality if exposed to sulfonylureas or exogenous insulin, compared with patients on metformin treatment (adjusted HR 1.3, 95\% CI 1.1-1.6; $\mathrm{p}=0.012$ and adjusted HR of 1.9 (95\% CI 1.5-2.4; $<<0.0001$, respectively) [86]. This observation was also confirmed in other studies when considering in particular $\mathrm{PaCa}[87,88]$ : metformin, contrarily to sulfonylureas or exogenous insulin, does not increase insulin levels and insulin itself is known to promote the growth of PaCa cells [89]. Metformin has also been shown, in a cell line study, to enhance the effect of different chemotherapeutic drug for $\mathrm{PaCa}$ treatment when used in combination [90]. Insulin resistance and compensatory hyperinsulinemia due to T2D is considered as a favourable condition for tumour growth [91]. Hyperinsulinemia causes the decrease of insulin like growth factor binding proteins (IGFBP-1 and 2) that results in a high level of circulating insulinlike growth factor-1 (IGF-1) in bloodstream. This growth factor may play a crucial role in cell proliferation and can interfere with sex hormones causing the typical differences of gender observed in PaCa risk [91].

\section{Metabolic Syndrome}

In the wider framework represented by the metabolic syndrome (MetS), biological processes occurring in diabetes and obesity, in addition to dyslipidaemia and hypertension, are strictly linked to each other and act synergistically enhancing the risk of developing several diseases. The combination of a different numbers of conditions, characterizing MetS, may act proportionally in enhancing the risk of $\mathrm{PaCa}$, and among these, diabetes is the strongest risk factor [92]. The presence of comorbidities places attention on the need to conceive studies not oriented only on individual conditions but on their interaction. In a European case-control study, two multimorbidity patterns, related to MetS and gastric illness, were found positively associated with PaCa even 
considering time and common background environmental and genetic aspects. In particular, T2D and gastric morbidity pattern showed together a greater PaCa risk regardless of diagnosis time (OR, 7.89; 95\% CI 3.9-16.1 and OR, 1.86; 95\% CI 1.29-2.67 in recent and long-term diagnosed, respectively) [93]. UK Biobank data had shown higher PaCa risk in individuals with MetS (HR = $1.31,95 \% \mathrm{CI}, 1.09-1.56)$, central obesity $(\mathrm{HR}=1.24,95 \% \mathrm{CI}, 1.02-1.50)$ and hyperglycemia $(\mathrm{HR}=$ $1.60,95 \% \mathrm{CI}, 1.31-1.97)$. These two last MetS components seem to show an independent association, whereas, the presence of MetS and elevated levels of $\mathrm{C}$ reactive protein (CRP) seems to increase PaCa risk [94].

In a recent study, the role of advanced glycation end products' (AGEs) accumulation, occurring also in aging and increased by obesity, diabetes, and smoking and western diet, has been underlined. NEcarboxymethyllysine (CML), the most common AGE in vivo, showed a strong capacity to enhance tumor cells growth in a time and concentration-dependent manner promoting the expression of AGE-receptors. These receptors can bind different ligands activating several inflammatory pathways such as nuclear factor (NF)- $\mathrm{kB}$ directly involved in the up-regulation of AGE-receptors. In addition, AGEs act at an early stage of tumor development accelerating the progression of $\mathrm{PaCa}$ from PanIN lesions [95].

\section{Infectious diseases}

Infectious diseases are known risk factors for three of the most common tumours (Hepatitis $B$ and $C$ and liver cancer, papillomavirus and cervical cancer, Helicobacter pylori and gastric cancer). However, the relation between $\mathrm{PaCa}$ and infectious disease is still unknown. A possible link has been proposed for Helicobacter pylori (H. pylori). A meta-analysis on 6 observational studies published until 2010 pointed out the existence of a significant association between H. pylori seropositivity and development of $\mathrm{PaCa}$ (adjusted OR 1.38, 95\% CI 1.08-1.75; $\mathrm{p}=0.009$ ) [96]. Moreover, a review of 117 meta-analytical or pooled reports identified $H$. pylori infection, along with tobacco smoking, as the major risk factors for $\mathrm{PaCa}$ with associated population attributable 
fractions of 4-25\% [97] although another subsequent meta-analysis did not confirm the results [98].

It has been calculated that with an estimated prevalence varying from $25 \%$ to $50 \%$ in Western countries, $H$. pylori infection could be responsible for $4-25 \%$ of cases of $\mathrm{PaCa}$ in that area [97]. $H$. pylori $16 \mathrm{~S}$ ribosomal DNA was detected in $75 \%$ of paraffin-embedded PaCa tissues while none resulted positive in the control group, thus supporting the hypothesis of a causal role played by $H$. pylori infection in the development of $\mathrm{PaCa}$ [99]. The carcinogenic mechanism of $H$. pylori infection is still not clear. A possible indirect action of $H$. pylori in PaCa development is linked with an increase of gastric acidity and high pancreatic stimulation by secretin. This phenomenon is strictly related to bacterial strain features since the cytotoxin-associated gene A (CagA) negative strain can induce hyperacidity and is associated to an increased risk whereas the CagA positive strain may have a protective action inducing gastric hypoacidity [100].

An additional study focusing on the effect of $H$. pylori on human pancreatic cancer cells, identified that infection induces interleukin-8 (IL-8) and vascular endothelial growth factor (VEGF) secretion, in addition to promote the activation of the transcription factors NF-kB, the increase of the activator protein-1 (AP-1) and serum response element (SRE), which can all promote the malignant potential of PaCa cells [101].

Though epidemiological studies continue to investigate the involvement of $H$. pylori on $\mathrm{PaCa}$ development, literature is still discordant: a population-based prospective cohort study (ESTHER) published in 2016 with a 10-year follow up and the EPIC nested case-control cohort study published in 2017 did not find any association [102, 103] .

Recently, several studies focused on the composition of oral microbiome and the correlation with $\mathrm{PaCa}$ incidence. Interestingly, independent studies identified a potential correlation between $\mathrm{PaCa}$ and $P$. gingivalis, one of the main etiologic agents of periodontal disease [104, 105], also involved in rheumatoid arthritis [106]. The EPIC prospective cohort study pointed out the existence of a twofold increase of PaCa risk in individuals with high levels of antibody against $P$. gingivalis in bloodstream. On the other hand, the increased levels of antibodies against commensal (non- 
pathogenic) oral bacteria are associated with a reduced risk of pancreatic cancer. This could be linked with the inhibition of pathogen bacterial growth [107]. Several mechanisms of $P$. gingivalis involvement in $\mathrm{PaCa}$ development have been proposed. A first mechanism may consist in the activation of carcinogens compound contained in cigarettes, such as nitrosamine, or the ability to convert ethanol into acetaldehyde. Secondly, $P$. gingivalis may activate the toll-like receptor (TLR) signaling pathways in dendritic cells. In particular, TLR4 overexpression has been found in $\mathrm{PaCa}$ cells and it may promote human $\mathrm{PaCa}[108,109]$. Furthermore $P$. gingivalis, may induce an inflammatory response in distant sites, suggesting that an abnormal immune function and the exposure to chronic inflammation could predispose to cancer, especially in adults.

\section{Psychological stress}

Psychological stress is a possible consequence of the complex relationship between human behavior and environmental context in coping with adverse life events. Although the individual's stress management is linked to specific gene variants, epigenetic effects or altered physiological mechanisms; it is still matter of debate how specific episodes can trigger significant behavioral problems with effects on the general health status [110]. Several studies have shown a link between severe and repeated psychological stress and cardiovascular diseases, immune diseases, tumors, as well as in tumor growth and the onset of metastases [111]. In a nationwide cohort study conducted in Sweden on 4,219,697 people, a severe emotional stress like the loss of a parent was linked with an increased risk of early-onset $\mathrm{PaCa}$ ( $<40$ years) regardless of age at loss and $\mathrm{PaCa}$ showed the strongest association with parental death among all the type of cancers considered [112] although the increased risk could be related to smoking, which is a wellknown lifestyle change after bereavement [113]. Similarly, the incidence of PaCa after the loss of a child showed comparable results [114]. A nested case-control study conducted in Sweden on 16,522 cases and 82,107 controls showed a slightly increased risk of $\mathrm{PaCa}$ after this traumatic event $(\mathrm{OR}=1.09,95 \%$ CI: $1.02,1.17)$ that became significant when considering the first 5 years after child 
461 loss, when the loss was due to a suicide and when considering persons with a history of psychiatric

462 illnesses [114].

463 Animal studies had proven that, after a psychological stress, the released neurotransmitters (e.g.

464 noradrenalin, adrenalin, cortisol) negatively impact the clinical outcome of $\mathrm{PaCa}$ promoting the 465 growth of the mouse xenografts [115]. The mechanism is mediated by the multiple activation of 466 cyclic adenosine 3', 5'-monophosphate (cAMP) and the concomitant inhibition of the $\gamma$ 467 aminobutiric acid (GABA) response. In fact the overall reduction of cAMP induced by GABA 468 treatment causes a decreased tumour growth and consequently the downregulation of the $\beta$ 469 adrenergic signalling pathway, that is strictly involved in the stress response [115].

470 Two independent studies in 2017 showed how the use of non-selective $\beta$-blockers, antiarrhythmic 471 drugs used also in chronic stress and depression, leads to a reduction of $\mathrm{PaCa}$ progression in 472 patients without metastasis $[116,117]$. These findings have been confirmed by a study on animal 473 models. They were subjected to immobilization for $2 \mathrm{~h} /$ day for a month and the changes in 474 pancreatic tumour growth rate caused by stress were observed. The samples analysed showed an 475 increased tumour growth and invasion of distant organs, compared to control, which is caused by 476 the overexpression of $\beta$-adrenergic signalling pathways since the blocking of these receptor with 477 propranolol contrasts tumour cells progression. Furthermore, the modulation of the receptor with 478 the $\beta$-adrenergic agonist isoprenaline, caused the overexpression of metalloproteinase 2 and 9 , 479 involved in tumour cell invasion [118]. The $\beta$-adrenergic receptors also mediate the stimulatory 480 effect of norepinephrine, a stress associated hormone, on pancreatic duct epithelial cells through the 481 activation of the beta-adrenergic dependent $\mathrm{p} 38 /$ mitogen-activated protein kinases (MAPK) 482 pathway $[119,120]$. Both sympathetic and parasympathetic system innerves the pancreas, and the 483 nerve density is higher in pancreatic tumor tissues. Through overexpression of $\beta$-adrenergic signaling (adrb2 up regulation), the psychological stress causes an increase in neurotrophins such as nerve growth factor and brain derived neurotrophic factor (BDNF) contributing to the nerve-tumor interaction by axogenesis [121]. The increased nerve growth factor (NGF) level is associated with a 
higher aggressiveness and worst prognosis in case of high expression of tropomyosin receptor kinase A (TrkA) compared to the expression of the low-affinity nerve growth factor receptor p75NGFR from tumor cells [122]. In addition, as demonstrated by a recent study in a mouse model, stress subjection can act on PaCa progression compromising the immune system activity through the reduction of cytokines production, interferon gamma (IFN- $\gamma$ ) and interleukins [7, 8, 10-12] along with reduction in T lymphocytes (CD4 cells) population and CTLA-4 (cytotoxic Tlymphocyte-associated protein 4) protein expression from these. Moreover, the increase of transforming growth factor beta (TGF- $\beta$ ) and vascular endothelial growth factor (VEGF) in chronically stressed mice is involved in PaCa growth and diffusion [123].

\section{DISCUSSION}

$\mathrm{PaCa}$ is a multifactorial disease related to genetic alterations and associated with known risk factors. Nutrition and life style are involved in $\mathrm{PaCa}$ both as a pathogenic and as preventative factor [124]. From the National Institutes of Health (NIH)-AARP Diet and Health study, it emerged that 27\% of cases of PaCa may have been prevented with a healthy lifestyle, which included the absence of smoke, limited alcohol intake, Mediterranean diet, normal weight and regular physical activity. Several causes have been proposed to be associated with an increasing risk of $\mathrm{PaCa}$ including a high-fat diet and the intake of fried food as well as red and processed meat [46]. On the other hand, foods which have been identified to be inversely related to the risk of developing PaCa include fresh fruit and vegetables $[125,126]$. The WCRF guidelines on cancer prevention suggest to limit the consumption of fat, added sugar rich food, red and processed meat and to have 5 portions per day of vegetables and fruit and fibre rich food such as whole grains and pulses [127]. Within the EPIC study a Healthy Lifestyle Index (HLI) was used to give a score to the effect of combined smoking, alcohol intake, dietary exposure, physical activity and central adiposity using BMI or WHR, respectively. Observed scores confirmed that a healthy lifestyle was found inversely related to PaCa risk [128]. 
513 Obesity plays a key role as PaCa risk factor and represents one of the biggest problems in the

514 United States with a forecast of people involved by 2030 of at least $44 \%$ in all 50 states of US and 515400,000 new obesity-related cancer cases in the next 2 decades with an increasing costs of 516 healthcare between $\$ 48$ billion and $\$ 66$ billion [129]. A possible explanation of the link between 517 obesity and $\mathrm{PaCa}$ resides in tumour-promoting inflammation and hormonal effects associated with 518 the accumulation of adipose tissue [68]. Body fatness stimulates insulin production in response to 519 increased levels of free-fatty acids released from adipose tissue promoting a state of insulin520 resistance as a compensatory mechanism [130]. It predisposes to the onset of T2D which is itself a 521 risk factor for $\mathrm{PaCa}$ suggested by the fact that $80 \%$ of patients with $\mathrm{PaCa}$ are affected by glucose intolerance or frank diabetes [131]. As a consequence, pancreas secretes more insulin triggering mitotic activity. Hyperinsulinemia has been demonstrated to increase local blood flow, the growth 524 of the exocrine part of the pancreas and a number of studies have confirmed the ability of insulin to 525 stimulate the growth of $\mathrm{PaCa}$ cell lines $[89,132]$. Another proposed mechanism that links obesity and $\mathrm{PaCa}$ resides in the formation of DNA adducts related to the formation of reactive oxygen species (ROS) and lipid peroxidation [133].

The relationship between T2D and PaCa has been widely investigated. However, the topic is still a matter of debate, also because the development of T2D is strongly associated with obesity, both conditions being in continuous increasing trend [134]. T2D as obesity is characterised by a condition of hyperglycaemia and hyperinsulinemia due to insulin resistance as part of MetS. Hyperglycaemia accompanies both long-standing and new outbreak diabetes. In the first case, diabetes is supposed to be the cause of $\mathrm{PaCa}$ and in the second one an expression of the tumour [80, 135]. There is several evidence to support that cancer is also the cause of T2D. From the literature, 535 it emerges that $25-50 \%$ of PaCa cases have been diagnosed with T2D 1-3 years before the diagnosis 536 of cancer $[78,136]$. Unfortunately, T2D alone is not a sufficient indicator to justify an invasive 537 intervention of screening given that only 1/50-100 new-onset diabetes cases observed will develop 538 $\mathrm{PaCa}[80,136]$. 
Multiple gene polymorphisms have been investigated in the association between cancer and T2D: the single nucleotide polymorphism $-23 \mathrm{HphI}(\mathrm{A} / \mathrm{T})$ located in the promoter region of the insulin gene may play a role in the pathogenesis of $\mathrm{PaCa}$ and could contribute to tumour staging [137]. In the hexokinase 2 gene, that is related to glucose metabolism, the genotype R844K GA/AA was found to increase the risk of $\mathrm{PaCa}$ in diabetic patients $(\mathrm{OR}=3.69 ; 95 \% \mathrm{CI}, 2.34-5.82)$ and to decrease it among the non-diabetic people $(\mathrm{OR}=0.68 ; 95 \% \mathrm{CI}, 0.56-0.83)$ [138].

In addition to obesity, there are other few established causes; one of the strongest is tobacco smoking. It is linked with the risk of developing $\mathrm{PaCa}$ in dose and time-dependent manner. The exposure to tobacco smoking products such as NNN, NNK and NNAL can cause PaCa in animal models as they can cause DNA mutations like the ones involving KRAS gene, the most common to be found in this disease $[26,27]$. Tobacco effect seems to be emphasized by alcohol consumption that is related as well to $\mathrm{PaCa}$ development when the intake is high.

Alcohol consumption causes the production of the oncogenic compound acetaldehyde, which is in turn an established risk factor for pancreatitis. From a meta-analysis by Duell et al. it emerges that who had a history of pancreatitis have a 6 fold increased risk to develop PaCa compared with controls [139]. Alcohol consumption is classified by the International Agency for Research on Cancer (IARC) as possible causes of PaCa. However, WCRF/AICR makes no judgment on the association between PaCa risk and alcohol consumption, due to limited evidence.

Epigenetic alterations such as DNA methylations has been studied in regards to nutrients (e.g. folate, vitamin $\mathrm{B}_{12}$, vitamin $\mathrm{B}_{6}$ ) [140] and a deficient diet in these nutrients may lead to DNA hypomethylation that could determine chromosome instability, frequently found in tumours [141]. The methods of cooking also influence the carcinogenic potential of other foods and a positive association has been reported for fried, grilled and barbequed foods in general [4]. The cooking of meat at high temperatures determines the production of HCAs and PAHs [141], mutagenic compounds that induce multiple tumours in animal models [142]. 
Life style, environmental and multifactorial factors affect therefore the risk of $\mathrm{PaCa}$ in different ways and levels. Table 1 summarises, in more details, some of the RR, OR and HR obtained from the most recent meta-analyses and some of the correlations identified between cancer risk and specific risk factors related to lifestyle, environment and disease in cohort or case-control studies.

\section{Pre-neoplastic lesion as additional factors}

Some of the factors affecting the development of $\mathrm{PaCa}$, and considered in this review, also play an important role in the development of IPMNs and MCNs lesions that can lead to PaC. Even if PanINs are the most important non-invasive precursor lesions linked to $\mathrm{PaCa}$ onset, they are more often found in PaCa patients with family history and linked to genetic mutations [143, 144]. A study carried out in a population of 390 IPMN patients, showed that history of chronic pancreatitis (OR: 10.10 , CI $95 \%: 1.30-78.32$ ), family history of PaCa (R: 2.94, CI $95 \%: 1.17-7.39$ ) and history of diabetes $(\mathrm{OR}, 1.79 ; 95 \% \mathrm{CI}, 1.08-2.98 ; \mathrm{P}=0.025)$ were independent risk factors for IPMN and that diabetics patients using insulin had a higher risk to develop IPMN (OR: 6.03, CI 95 $\%: 1.74-20.84$ ), suggesting an overlap between certain risk factors for IPMN and PaCa [145]. Moreover, in IPMN patients, T2D was associated with more frequent main-duct involvement and worse progression of IPMN into high-grade dysplasia and 2.7-fold higher risk to develop invasive $\mathrm{PaCa}[146]$.

\section{Inflammation as common mechanism to investigated risk factors}

This review has highlighted inflammation as potential mechanism common to the considered lifestyle and environmental factors, and diseases, and increased risk to develop PaCa. To this extent and to support such hypothesis, few studies have highlighted the inverse association between use of drugs such as aspirin and statins and cancer development. A meta-analysis carried out by Bosetti et al. [147] showed a correlation between regular aspirin use and reduction of the risk to develop pancreatic cancer $(\mathrm{RR}=0.78,95 \% \mathrm{CI}: 0.68 \mathrm{e} 0.89)$ and an inverse duration-risk relations with aspirin use. Similar findings were observed in a previous meta-analysis which focused specifically on $\mathrm{PaCa}$ and highlighted aspirin use to led to decreased $\mathrm{PaCa}$ incidence but not to reduction of mortality (OR 
$=0.94 ; 95 \% \mathrm{CI}=0.73$ to 1.22 ), whereas non-aspirin NSAIDs (non steroidal anti-inflammatory drugs) were not significantly related with PaCa risk decrease [148]. Furthermore, the use of large dose of aspirin was found to be preventive when continued for at least 5 years [149].

Statins use was also investigated as possible preventive factor for PaCa. Recent meta-analyses found that statin use was inversely correlated with $\mathrm{PaCa}$ development, with an overall $\mathrm{PaCa}$ risk reduction among statin users of 30\% (OR 0.70;95\% CI 0.60-0.82; $\mathrm{p}<0.0001)$, in respect to nonusers $[150,151]$. Furthermore, the use of statin has been linked to a survival improvement and mortality reduction in $\mathrm{PaCA}$ patients (meta-HR $=0.75 ; 95 \% \mathrm{CI}: 0.59,0.90 ; \mathrm{P}<0.001)$ and proposed as possible therapy for this disease $[152,153]$. The mechanism, by which these two drugs may affect cancer development and progression, is not fully known. It is hypothesized that aspirin proposed cancer preventive mechanisms may be mediated by platelets inactivation, similar to its cardioprotective effect: differently from others NSAIDs, aspirin inhibits cyclooxygenase (COX) pathways through acetylation of COX isoforms' serine residues (Ser 516 and Ser529) blocking them in an irreversible way and forcing cells to synthetize de novo the enzyme. In relation to statins, there are different plausible mechanisms through which this drug may influence $\mathrm{PaCa}$ development [154]: statin blocks conversion of the3-hydroxy-3-methyl-glutaryl-coenzyme A (HMG-CoA) into mevalonate which is the precursor of different molecules such as isoprenoids involved in activation of different signalling cascades involved in tumorigenesis and cancer progression such as RAS, RAF/MEK/ERK, mTOR and Bcl-2 [154, 155]. Interestingly, statins showed also immunomodulatory, antiproliferative and antiangiogenic effect and can inhibit matrix metalloproteinases also involved in cancer invasion and metastasis. Taken together these properties may explain the possible protective effect from $\mathrm{PaCa}[150]$.

\section{Limitations and future directives}

Although the present review has shown evidence of several life style or behavioural condition that are linked with $\mathrm{PaCa}$ by plausible biological processes, the study and the assessment of the different risk factors still represent a challenge for several reasons. 
First, there are many risks factors that combined together predispose to the onset of $\mathrm{PaCa}$ and

617 studies matching those together are still missing. A full risk factor assessment should be completed, 618 and results should be adjusted by the weight of each potential risk factor. Therefore, we should 619 always keep in mind that epidemiological studies are simplified and that reality is far more complex 620 than a scientific model, indispensable in any case to conduct scientific research.

621 Secondly, when the scientific community move to epidemiological studies (prospective cohort 622 studies and retrospective case-control studies) and clinical trials, the results are often conflicting and 623 inconclusive. There could be many explanations for this, including, for example, the type of 624 epidemiological studies conducted. Prospective cohort studies are ideal for studies that assess the relation between dietary factors and diseases such as cancer [156]. A large number of people could be involved and the questionnaires about food habits and life-style factors are less affected by bias. However problems reside in the fact that follow-up needs to be conducted for several years and often the number of cases observed is too small to draw conclusive results [157]. On the other hand, 629 a far greater number of retrospective case-control studies have been lead. They require shorter time to be carried out and a larger number of cases could be included. However, the biggest limitation is represented by the fact that questionnaires are filled retrospectively placing the study at risk of recall bias.

633 For all of these reasons, the recognized environmental risk factors involved in $\mathrm{PaCa}$ are still few 634 and not overall recognized as directly involved in tumour occurrence. Despite $\mathrm{PaCa}$ is rarer than 635 other cancer types, it is one of the most aggressive and deadly with one of the lowest survival rate. By 2030, it is projected to become the second cause of cancer death [75]. Based on the presented 638 and the intake of food and the behavioural attitudes known to be related to cancer onset should be 639 limited. 
642 SZ, PB, FG and GB conceptualized the study, SR and ARL identified relevant literature. SR, ARL, $643 \mathrm{SZ}, \mathrm{FG}$ and GB wrote the manuscript, and all the authors reviewed manuscript.

644

645 Conflict of interest statement

646 None declared.

647

648 Acknowledgements

649 This work was supported by the Centre for Obesity Research and Education, Robert Gordon 650 University, Aberdeen.

651 


\section{REFERENCES}

653 [1] Siegel RL, Miller KD, Jemal A. Cancer statistics, 2018. CA: a cancer journal for clinicians. 2018;68(1):7-30.

[2] http://www.cancerresearchuk.org/health-professional/cancer-statistics/statistics-by-cancertype/pancreatic-cancer

[3] Ryerson AB, Eheman CR, Altekruse SF, Ward JW, Jemal A, Sherman RL, et al. Annual Report to the Nation on the Status of Cancer, 1975-2012, featuring the increasing incidence of liver cancer. Cancer. 2016;122(9):1312-37.

[4] Ghadirian P, Lynch HT, Krewski D. Epidemiology of pancreatic cancer: an overview.

[5] Petersen GM, de Andrade M, Goggins M, Hruban RH, Bondy M, Korczak JF, et al.

[6] Eldridge RC, Gapstur SM, Newton CC, Goodman M, Patel AV, Jacobs EJ. Jewish ethnicity Pancreatic cancer genetic epidemiology consortium. Cancer epidemiology, biomarkers \& prevention. 2006;15(4):704-10. and pancreatic cancer mortality in a large U.S. cohort. Cancer epidemiology, biomarkers \& prevention. 2011;20(4):691-8.

[7] Lim JE, Chien MW, Earle CC. Prognostic factors following curative resection for pancreatic adenocarcinoma: a population-based, linked database analysis of 396 patients. Ann Surg. 2003;237(1):74-85.

[8] Yeo TP, Hruban RH, Leach SD, Wilentz RE, Sohn TA, Kern SE, et al. Pancreatic cancer. Current problems in cancer. 2002;26(4):176-275.

[9] Cervantes A, Waymouth EK, Petrov MS. African-Americans and Indigenous Peoples Have Increased Burden of Diseases of the Exocrine Pancreas: A Systematic Review and MetaAnalysis Dig Dis Sci. 2019;64(1):249-261

[10] Jones S, Zhang X, Parsons DW, Lin JC, Leary RJ, Angenendt P, et al. Core signaling pathways in human pancreatic cancers revealed by global genomic analyses. Science. 2008;321(5897):1801-6.

[11] Giovinazzo F, Turri G, Zanini S, Butturini G, Scarpa A, Bassi C. Clinical implications of biological markers in Pancreatic Ductal Adenocarcinoma. Surgical oncology. 2012;21(4):e171-82.

[12] Pang Y, Holmes MV, Chen Z, Kartsonaki C. A review of lifestyle, metabolic risk factors, and blood-based biomarkers for early diagnosis of pancreatic ductal adenocarcinoma. $\mathrm{J}$ Gastroenterol Hepatol. 2019; 34(2):330-345

[13] Research WCRF/AIRC. Continous Update Project. Food, Nutrition, Physical Activity, and the prevention of Pancreatic Cancer. Available at http://wwwdietandcancerreportorg. 2012.

[14] http://globocan.iarc.fr/Pages/online.aspx

[15] Lynch SM, Vrieling A, Lubin JH, Kraft P, Mendelsohn JB, Hartge P, et al. Cigarette smoking and pancreatic cancer: a pooled analysis from the pancreatic cancer cohort consortium. Am J Epidemiol. 2009;170(4):403-13.

[16] Iodice S, Gandini S, Maisonneuve P, Lowenfels AB. Tobacco and the risk of pancreatic cancer: a review and meta-analysis. Langenbeck's archives of surgery 2008;393(4):535-45.

[17] Gandini S, Botteri E, Iodice S, Boniol M, Lowenfels AB, Maisonneuve P, et al. Tobacco smoking and cancer: a meta-analysis. Int J Cancer. 2008; 122(1):155-64. 
[18] Lugo A, Peveri G, Bosetti C, Bagnardi V, Crippa A, Orsini N, et al. Strong excess risk of pancreatic cancer for low frequency and duration of cigarette smoking: A comprehensive review and meta-analysis. Eur J Cancer. 2018; 104:117-126

698

[19] Jiao L, Mitrou PN, Reedy J, Graubard BI, Hollenbeck AR, Schatzkin A, et al. A combined healthy lifestyle score and risk of pancreatic cancer in a large cohort study. Archives of internal medicine. 2009;169(8):764-70.

[20] Romaszko-Wojtowicz A, Buciński A, Doboszyńska A. Impact of smoking on multiple primary cancers survival: a retrospective analysis. Clin Exp Med.2018; 18(3):391-397.

[21] Duell EJ. Epidemiology and potential mechanisms of tobacco smoking and heavy alcohol consumption in pancreatic cancer. Molecular carcinogenesis. 2012;51(1):40-52.

[22] Zou L, Zhong R, Shen N, Chen W, Zhu B, Ke J, et al. Non-linear dose-response relationship between cigarette smoking and pancreatic cancer risk: evidence from a meta-analysis of 42 observational studies. European journal of cancer. 2014;50(1):193-203.

[23] Ben QW, Liu J, Sun YW, Wang LF, Zou DW, Yuan YZ. Cigarette Smoking and Mortality in Patients With Pancreatic Cancer: A Systematic Review and Meta-analysis. Pancreas. 2019 48(8):985-995.

[24] Yuan C, Morales-Oyarvide V, Babic A, Clish CB, Kraft P, Bao Y, et al. Cigarette Smoking and Pancreatic Cancer Survival. J Clin Oncol. 2017;35(16):1822-8.

[25] Zhou J, Wellenius GA, Michaud DS. Environmental tobacco smoke and the risk of pancreatic cancer among non-smokers: a meta-analysis. Occup Environ Med. 2012; 69(12):853-7.

[26] Rivenson A, Hoffmann D, Prokopczyk B, Amin S, Hecht SS. Induction of lung and exocrine pancreas tumors in F344 rats by tobacco-specific and Areca-derived N-nitrosamines. Cancer research. 1988;48(23):6912-7.

[27] Schuller HM. Mechanisms of smoking-related lung and pancreatic adenocarcinoma development. Nature reviews Cancer. 2002;2(6):455-63.

[28] Hermann PC, Sancho P, Cañamero M, Martinelli P, Madriles F, Michl P, et al. Nicotine promotes initiation and progression of KRAS-induced pancreatic cancer via Gata6dependent dedifferentiation of acinar cells in mice. Gastroenterology. 2014;147(5):111933.e4.

[29] Tramacere I, Scotti L, Jenab M, Bagnardi V, Bellocco R, Rota M, et al. Alcohol drinking and pancreatic cancer risk: a meta-analysis of the dose-risk relation. International journal of cancer. 2010;126(6):1474-86.

[30] Naudin S, Li K, Jaouen T, Assi N, Kyrø C, Tjønneland A, et al. Lifetime and baseline alcohol intakes and risk of pancreatic cancer in the European Prospective Investigation into Cancer and Nutrition study. Int J Cancer. 2018; 15;143(4):801-812.

[31] Wang YT, Gou YW, Jin WW, Xiao M, Fang HY. Association between alcohol intake and the risk of pancreatic cancer: a dose-response meta-analysis of cohort studies. BMC cancer. 2016;16:212.

[32] Rosato V, Polesel J, Bosetti C, Serraino D, Negri E, La Vecchia C. Population attributable risk for pancreatic cancer in Northern Italy. Pancreas. 2015;44(2):216-20.

[33] Seitz HK, Stickel F. Molecular mechanisms of alcohol-mediated carcinogenesis. Nature reviews Cancer. 2007;7(8):599-612.

[34] Criddle DN, Raraty MG, Neoptolemos JP, Tepikin AV, Petersen OH, Sutton R. Ethanol toxicity in pancreatic acinar cells: mediation by nonoxidative fatty acid metabolites. 
[35] Kolodecik T, Shugrue C, Ashat M, Thrower EC. Risk factors for pancreatic cancer: underlying mechanisms and potential targets. Frontiers in physiology. 2013;4:415.

[36] Gukovsky I, Pandol SJ, Mareninova OA, Shalbueva N, Jia W, Gukovskaya AS. Impaired autophagy and organellar dysfunction in pancreatitis. J Gastroenterol Hepatol. 2012;27

[37] Port AM, Ruth MR, Istfan NW. Fructose consumption and cancer: is there a connection? Curr Opin Endocrinol Diabetes Obes. 2012;19(5):367-74.

[38] Tasevska N, Park Y, Jiao L, Hollenbeck A, Subar AF, Potischman N. Sugars and risk of mortality in the NIH-AARP Diet and Health Study. Am J Clin Nutr. 2014;99(5):1077-88.

[39] Larsson SC, Bergkvist L, Wolk A. Consumption of sugar and sugar-sweetened foods and the risk of pancreatic cancer in a prospective study. Am J Clin Nutr. 2006;84(5):1171-6.

[40] Schernhammer ES, Hu FB, Giovannucci E, Michaud DS, Colditz GA, Stampfer MJ, et al. Sugar-sweetened soft drink consumption and risk of pancreatic cancer in two prospective cohorts. Cancer epidemiology, biomarkers \& prevention. 2005;14(9):2098-105.

[41] Jiao L, Flood A, Subar AF, Hollenbeck AR, Schatzkin A, Stolzenberg-Solomon R. Glycemic index, carbohydrates, glycemic load, and the risk of pancreatic cancer in a prospective cohort study. Cancer epidemiology, biomarkers \& prevention 2009;18(4):114451.

[42] Aune D, Greenwood DC, Chan DS, Vieira R, Vieira AR, Navarro Rosenblatt DA, et al. Body mass index, abdominal fatness and pancreatic cancer risk: a systematic review and non-linear dose-response meta-analysis of prospective studies. Ann Oncol. 2012; 23(4):84352.

[43] Charrez B, Qiao L, Hebbard L. The role of fructose in metabolism and cancer. Horm Mol Biol Clin Investig. 2015;22(2):79-89.

[44] Samuel VT. Fructose induced lipogenesis: from sugar to fat to insulin resistance. Trends in endocrinology and metabolism. 2011;22(2):60-5.

[45] Hsieh CC, Shyr YM, Liao WY, Chen TH, Wang SE, Lu PC, et al. Elevation of $\beta$ galactoside $\alpha 2,6$-sialyltransferase 1 in a fructose-responsive manner promotes pancreatic cancer metastasis. Oncotarget. 2017 Jan 31; 8(5): 7691-7709.

[46] Larsson SC, Håkanson N, Permert J, Wolk A. Meat, fish, poultry and egg consumption in relation to risk of pancreatic cancer: a prospective study. Int J Cancer. 2006; 118(11):286670 .

[47] Nothlings U, Wilkens LR, Murphy SP, Hankin JH, Henderson BE, Kolonel LN. Meat and fat intake as risk factors for pancreatic cancer: the multiethnic cohort study. Journal of the National Cancer Institute. 2005;97(19):1458-65.

[48] Rohrmann S, Linseisen J, Nothlings U, Overvad K, Egeberg R, Tjonneland A, et al. Meat and fish consumption and risk of pancreatic cancer: results from the European Prospective Investigation into Cancer and Nutrition. International journal of cancer 2013;132(3):617-24.

[49] Chiang VS, Quek SY. The relationship of red meat with cancer: Effects of thermal processing and related physiological mechanisms. Crit Rev Food Sci Nutr. 2017;57(6):115373. 
[50] Taunk P, Hecht E, Stolzenberg-Solomon R. Are meat and heme iron intake associated with pancreatic cancer? Results from the NIH-AARP diet and health cohort. International journal of cancer. 2016;138(9):2172-89.

[51] Belpomme D, Irigaray P, Hardell L, Clapp R, Montagnier L, Epstein S, et al. The multitude and diversity of environmental carcinogens. Environ Res. 2007;105(3):414-29.

[52] Becker K, Seiwert M, Angerer J, Heger W, Koch HM, Nagorka R, et al. DEHP metabolites in urine of children and DEHP in house dust. Int J Hyg Environ Health. 2004;207(5):409-17.

[53] Rajesh P, Balasubramanian K. Gestational exposure to di(2-ethylhexyl) phthalate (DEHP) impairs pancreatic beta-cell function in F1 rat offspring. Toxicol Lett. 2015;232(1):46-57.

[54] Caldwell JC. DEHP: genotoxicity and potential carcinogenic mechanisms-a review. Mutat Res. 2012;751(2):82-157.

[55] Schwartz GG, Reis IM. Is cadmium a cause of human pancreatic cancer? Cancer epidemiology, biomarkers \& prevention. 2000;9(2):139-45.

[56] Lemus R, Abdelghani AA, Akers TG, Horner WE. Health risks from exposure to metals in household dusts. Rev Environ Health. 1996;11(4):179-89.

[57] Tchounwou PB, Abdelghani AA, Pramar YV, Heyer LR, Steward CM. Assessment of potential health risks associated with ingesting heavy metals in fish collected from a hazardous-waste contaminated wetland in Louisiana, USA. Rev Environ Health. 1996;11(4):191-203.

[58] Luckett BG, Su LJ, Rood JC, Fontham ET. Cadmium exposure and pancreatic cancer in south Louisiana. J Environ Public Health. 2012:180186.

[59] Wei Yu YM, Rakesh Srivastava, Sharmila Shankar. Mechanistic role of heavy metal cadmium exposure in the etiology of pancreatic cancer. [abstract].In: Proceedings of the 107th Annual Meeting of the American Association for Cancer Research; 2016 Apr 16$20 ;:$ Abstract nr 4065.

[60] Amaral AF, Porta M, Silverman DT, Milne RL, Kogevinas M, Rothman N, et al. Pancreatic cancer risk and levels of trace elements. Gut. 2012;61(11):1583-8.

[61] Camargo J, Pumarega JA, Alguacil J, Sanz-Gallén P, Gasull M, Delclos GL, et al. Toenail concentrations of trace elements and occupational history in pancreatic cancer. Environ Int. $2019 ; 127: 216-225$.

[62] Garcia-Esquinas E, Pollan M, Umans JG, Francesconi KA, Goessler W, Guallar E, et al. Arsenic exposure and cancer mortality in a US-based prospective cohort: the strong heart study. Cancer epidemiology, biomarkers \& prevention 2013;22(11):1944-53.

[63] Nunez O, Fernandez-Navarro P, Martin-Mendez I, Bel-Lan A, Locutura JF, Lopez-Abente G. Arsenic and chromium topsoil levels and cancer mortality in Spain. Environ Sci Pollut Res Int. 2016;23(17):17664-75.

[64] Antwi SO, Eckert EC, Sabaque CV, Leof ER, Hawthorne KM, Bamlet WR, et al. Exposure to environmental chemicals and heavy metals, and risk of pancreatic cancer. Cancer causes \& control. 2015;26(11):1583-91.

[65] Alguacil J, Porta M, Kauppinen T, Malats N, Kogevinas M, Carrato A, et al. Occupational exposure to dyes, metals, polycyclic aromatic hydrocarbons and other agents and K-ras activation in human exocrine pancreatic cancer. International journal of cancer 2003;107(4):635-41.

[66] Malnick SD, Knobler H. The medical complications of obesity. QJM. 2006;99(9):565-79. 
[67] Rawla P, Thandra KC, Sunkara T. Pancreatic cancer and obesity: epidemiology, mechanism, and preventive strategies. Clin J Gastroenterol. 2019; 12(4):285-291 2019

[68] Donohoe CL, Doyle SL, Reynolds JV. Visceral adiposity, insulin resistance and cancer risk. Diabetol Metab Syndr. 2011;3:12.

[69] Li D, Morris JS, Liu J, Hassan MM, Day RS, Bondy ML, et al. Body mass index and risk, age of onset, and survival in patients with pancreatic cancer. JAMA 2009;301(24):2553-62.

[70] Genkinger JM, Spiegelman D, Anderson KE, Bernstein L, van den Brandt PA, Calle EE, et al. A pooled analysis of 14 cohort studies of anthropometric factors and pancreatic cancer risk. International journal of cancer. 2011;129(7):1708-17.

[71] Arslan AA, Helzlsouer KJ, Kooperberg C, Shu XO, Steplowski E, Bueno-de-Mesquita HB, et al. Anthropometric measures, body mass index, and pancreatic cancer: a pooled analysis from the Pancreatic Cancer Cohort Consortium (PanScan). Archives of internal medicine. 2010;170(9):791-802.

[72] Koyanagi YN, Matsuo K, Ito H, Tamakoshi A, Sugawara Y, Hidaka A, et al. Body-Mass Index and Pancreatic Cancer Incidence: A Pooled Analysis of Nine Population-Based Cohort Studies With More Than 340,000 Japanese Subjects. J Epidemiol. 2018;28(5):24552.

[73] Jiao L, Chen L, White DL, Tinker L, Chlebowski RT, Van Horn LV, et al. Low-fat Dietary Pattern and Pancreatic Cancer Risk in the Women's Health Initiative Dietary Modification Randomized Controlled Trial. Journal of the National Cancer Institute. 2018;110(1).

[74] Kliemann N, Murphy N, Viallon V, Freisling H, Tsilidis KK, Rinaldi S, et al. Predicted basal metabolic rate and cancer risk in the European prospective investigation into cancer and nutrition (EPIC). Int J Cancer. 2019; Oct 25. doi: 10.1002/ijc.32753

[75] Rahib L, Smith BD, Aizenberg R, Rosenzweig AB, Fleshman JM, Matrisian LM. Projecting cancer incidence and deaths to 2030: the unexpected burden of thyroid, liver, and pancreas cancers in the United States. Cancer research. 2014;74(11):2913-21.

[76] Dandona P, Aljada A, Bandyopadhyay A. Inflammation: the link between insulin resistance, obesity and diabetes. Trends Immunol. 2004;25(1):4-7.

[77] Zheng J, Wirth MD, Merchant AT, Zhang J, Shivappa N, Stolzenberg-Solomon RZ, et al. Inflammatory potential of diet, inflammation-related lifestyle factors and risk of pancreatic cancer: Results from the NIH-AARP Diet and Health Study. Cancer Epidemiol Biomarkers Prev. 2019; 28(7):1266-1270.

[78] Huxley R, Ansary-Moghaddam A, Berrington de Gonzalez A, Barzi F, Woodward M. TypeII diabetes and pancreatic cancer: a meta-analysis of 36 studies. British journal of cancer. 2005;92(11):2076-83.

[79] Ben Q, Xu M, Ning X, Liu J, Hong S, Huang W, et al. Diabetes mellitus and risk of pancreatic cancer: A meta-analysis of cohort studies. European journal of cancer 2011;47(13):1928-37.

[80] Magruder JT, Elahi D, Andersen DK. Diabetes and pancreatic cancer: chicken or egg? Pancreas. 2011;40(3):339-51.

[81] Jee SH, Ohrr H, Sull JW, Yun JE, Ji M, Samet JM. Fasting serum glucose level and cancer risk in Korean men and women. JAMA. 2005;293(2):194-202.

[82] Molina-Montes E, Coscia C, Gómez-Rubio P, Fernández A, Boenink R, Rava M et al. Deciphering the complex interplay between pancreatic cancer, diabetes mellitus subtypes and obesity/BMI through causal inference and mediation analyses. Gut 2020;0:1-11. doi:10.1136/gutjnl-2019-319990 
[83] Butler AE, Galasso R, Matveyenko A, Rizza RA, Dry S, Butler PC. Pancreatic duct replication is increased with obesity and type 2 diabetes in humans. Diabetologia. 2010;53(1):21-6.

[84] Fryzek JP, Garabrant DH, Schenk M, Kinnard M, Greenson JK, Sarkar FH. The association between selected risk factors for pancreatic cancer and the expression of p53 and K-ras codon 12 mutations. International journal of gastrointestinal cancer. 2006;37(4):139-45.

[85] Karnevi E, Sasor A, Hilmersson KS, Ansari D, Erjefalt JS, Rosendahl AH, et al. Intratumoural leukocyte infiltration is a prognostic indicator among pancreatic cancer patients with type 2 diabetes. Pancreatology. 2018;18(1):85-93.

[86] Bowker SL, Majumdar SR, Veugelers P, Johnson JA. Increased cancer-related mortality for patients with type 2 diabetes who use sulfonylureas or insulin. Diabetes Care. 2006;29(2):254-8.

[87] Li D, Yeung SC, Hassan MM, Konopleva M, Abbruzzese JL. Antidiabetic therapies affect risk of pancreatic cancer. Gastroenterology. 2009;137(2):482-8.

[88] Currie CJ, Poole CD, Gale EA. The influence of glucose-lowering therapies on cancer risk in type 2 diabetes. Diabetologia. 2009;52(9):1766-77.

[89] Fisher WE, Boros LG, Schirmer WJ. Insulin promotes pancreatic cancer: evidence for endocrine influence on exocrine pancreatic tumors. The Journal of surgical research. 1996;63(1):310-3.

[90] Candido S, Abrams SL, Steelman L, Lertpiriyapong K, Martelli AM, Cocco L, et al. Metformin influences drug sensitivity in pancreatic cancer cells. Adv Biol Regul. 2018;68:13-30.

[91] Carreras-Torres R, Johansson M, Haycock PC, Wade KH, Relton CL, Martin RM, et al. Obesity, metabolic factors and risk of different histological types of lung cancer: A Mendelian randomization study. PloS one. 2017;12(6):e0177875.

[92] Rosato V, Tavani A, Bosetti C, Pelucchi C, Talamini R, Polesel J, et al. Metabolic syndrome and pancreatic cancer risk: a case-control study in Italy and meta-analysis. Metabolism. 2011;60(10):1372-8.

[93] Gomez-Rubio P, Rosato V, Marquez M, Bosetti C, Molina-Montes E, Rava M et al. A systems approach identifies time-dependent associations of multimorbidities with pancreatic cancer risk. Annals of Oncology. 2017;28: 1618-1624.

[94] Xia B, He Q, Pan Y, Gao F, Liu A, Tang Y et al. Metabolic syndrome and risk of pancreatic cancer: A population-based prospective cohort study. Int J Cancer 2020 Jun 24.doi: 10.1002/ijc.33172.

[95] Menini S, Iacobini C, de Latouliere L, Manni I, Ionta V, Blasetti Fantauzzi C, et al. The advanced glycation end-product $\mathrm{N}()$-carboxymethyllysine promotes progression of pancreatic cancer: implications for diabetes-associated risk and its prevention. The Journal of Pathology. 2018;245(2):197-208.

[96] Trikudanathan G, Philip A, Dasanu CA, Baker WL. Association between Helicobacter pylori infection and pancreatic cancer. A cumulative meta-analysis. Journal of the pancreas. 2011;12(1):26-31.

[97] Maisonneuve P, Lowenfels AB. Risk factors for pancreatic cancer: a summary review of meta-analytical studies. Int J Epidemiol. 2015;44(1):186-98.

[98] Wang Y, Zhang FC, Wang YJ. Helicobacter pylori and pancreatic cancer risk: a metaanalysis based on 2,049 cases and 2,861 controls. APJCP. 2014;15(11):4449-54. 
[99] Nilsson HO, Stenram U, Ihse I, Wadstrom T. Helicobacter species ribosomal DNA in the pancreas, stomach and duodenum of pancreatic cancer patients. World journal of gastroenterology. 2006;12(19):3038-43.

[100] Schulte A, Pandeya N, Fawcett J, Fritschi L, Risch HA, Webb PM, et al. Association between Helicobacter pylori and pancreatic cancer risk: a meta-analysis. Cancer causes \& control. 2015;26(7):1027-35.

[101] Takayama S, Takahashi H, Matsuo Y, Okada Y, Manabe T. Effects of Helicobacter pylori infection on human pancreatic cancer cell line. Hepatogastroenterology. 2007;54(80):238791.

[102] Huang J, Zagai U, Hallmans G, Nyren O, Engstrand L, Stolzenberg-Solomon R, et al. Helicobacter pylori infection, chronic corpus atrophic gastritis and pancreatic cancer risk in the European Prospective Investigation into Cancer and Nutrition (EPIC) cohort: A nested case-control study. International journal of cancer. 2017;140(8):1727-35.

[103] Chen XZ, Schottker B, Castro FA, Chen H, Zhang Y, Holleczek B, et al. Association of helicobacter pylori infection and chronic atrophic gastritis with risk of colonic, pancreatic and gastric cancer: A ten-year follow-up of the ESTHER cohort study. Oncotarget. 2016;7(13):17182-93.

[104] Pihlstrom BL, Michalowicz BS, Johnson NW. Periodontal diseases. Lancet. 2005;366(9499):1809-20.

[105] Chang JS, Tsai CR, Chen LT, Shan YS. Investigating the Association Between Periodontal Disease and Risk of Pancreatic Cancer. Pancreas. 2016;45(1):134-41.

[106] Wegner N, Wait R, Sroka A, Eick S, Nguyen KA, Lundberg K, et al. Peptidylarginine deiminase from Porphyromonas gingivalis citrullinates human fibrinogen and alpha-enolase: implications for autoimmunity in rheumatoid arthritis. Arthritis Rheum. 2010;62(9):266272 .

[107] Michaud DS, Vrieling A, Jiao L, Mendelsohn JB, Steplowski E, Lynch SM, et al. Alcohol intake and pancreatic cancer: a pooled analysis from the pancreatic cancer cohort consortium (PanScan). Cancer Causes Control. 2010; 21(8):1213-25.

[108] Michaud DS, Izard J. Microbiota, oral microbiome, and pancreatic cancer. Cancer J. 2014;20(3):203-6.

[109] Zhang JJ, Wu HS, Wang L, Tian Y, Zhang JH, Wu HL. Expression and significance of TLR4 and HIF-1alpha in pancreatic ductal adenocarcinoma. World journal of gastroenterology. 2010;16(23):2881-8.

[110] Fogelman N, Canli T. Early Life Stress, Physiology, and Genetics: A Review. Front Psychol. 2019, 10:1668.

[111] Shin KJ, Lee YJ, Yang YR, Park S, Suh PG, Follo MY, Cocco L et al., Molecular Mechanisms Underlying Psychological Stress and Cancer. Curr Pharm Des. 2016;22(16):2389-402.

[112] Kennedy B, Valdimarsdóttir U, Sundström K, Sparén P, Lambe M, Fall K, et al. Loss of a parent and the risk of cancer in early life: a nationwide cohort study. Cancer causes \& control. 2014;25(4):499-506.

[113] Anda RF, Williamson DF, Escobedo LG, Mast EE, Giovino GA, Remington PL. Depression and the dynamics of smoking. A national perspective. JAMA 1990;264(12):1541-5.

[114] Huang J, Valdimarsdóttir U, Fall K, Ye W, Fang F. Pancreatic cancer risk after loss of a child: a register-based study in Sweden during 1991-2009. Am J Epidemiol. 2013;178(4):582-9. 
[115] Schuller HM, Al-Wadei HA, Ullah MF, Plummer HK. Regulation of pancreatic cancer by neuropsychological stress responses: a novel target for intervention. Carcinogenesis. 2012;33(1):191-6.

[116] Udumyan R, Montgomery S, Fang F, Almroth H, Valdimarsdottir U, Ekbom A, et al. BetaBlocker Drug Use and Survival among Patients with Pancreatic Adenocarcinoma. Cancer research. 2017;77(13):3700-7.

[117] Beg MS, Gupta A, Sher D, Ali S, Khan S, Gao A, et al. Impact of Concurrent Medication Use on Pancreatic Cancer Survival-SEER-Medicare Analysis. American journal of clinical oncology. 2018;41(8):766-71.

[118] Kim-Fuchs C, Le CP, Pimentel MA, Shackleford D, Ferrari D, Angst E, et al. Chronic stress accelerates pancreatic cancer growth and invasion: a critical role for beta-adrenergic signaling in the pancreatic microenvironment. Brain Behav Immun. 2014;40:40-7.

[119] Chan C, Lin HJ, Lin J. Stress-associated hormone, norepinephrine, increases proliferation and IL-6 levels of human pancreatic duct epithelial cells and can be inhibited by the dietary agent, sulforaphane. Int J Oncol. 2008;33(2):415-9.

[120] Huang XY, Wang HC, Yuan Z, Huang J, Zheng Q. Norepinephrine stimulates pancreatic cancer cell proliferation, migration and invasion via $\beta$-adrenergic receptor-dependent activation of P38/MAPK pathway. Hepatogastroenterology. 2012;59(115):889-93.

[121] Renz BW, Takahashi R, Tanaka T, Macchini M, Hayakawa Y, Dantes Z, et al. beta2 Adrenergic-Neurotrophin Feedforward Loop Promotes Pancreatic Cancer. Cancer cell. 2018;33(1):75-90 e7.

[122] Dang C, Zhang Y, Ma Q, Shimahara Y. Expression of nerve growth factor receptors is correlated with progression and prognosis of human pancreatic cancer. J Gastroenterol Hepatol. 2006;21(5):850-8.

[123] Partecke LI, Speerforck S, Kading A, Seubert F, Kuhn S, Lorenz E, et al. Chronic stress increases experimental pancreatic cancer growth, reduces survival and can be antagonised by beta-adrenergic receptor blockade. Pancreatology. 2016;16(3):423-33.

[124] Tsai HJ, Chang JS. Environmental Risk Factors of Pancreatic Cancer. J Clin Med. 2019; 8(9). pii: E1427.

[125] Jansen RJ, Robinson DP, Stolzenberg-Solomon RZ, Bamlet WR, de Andrade M, Oberg AL, et al. Fruit and vegetable consumption is inversely associated with having pancreatic cancer. Cancer causes \& control. 2011;22(12):1613-25.

[126] Yamagiwa Y, Sawada N, Shimazu T, Yamaji T, Goto A, Takachi R, et al. Fruit and vegetable intake and pancreatic cancer risk in a population-based cohort study in Japan. Int J Cancer. 2019; 144(8):1858-1866.

[127] http://www.wcrf.org. Our Cancer Prevention Recommendations.

[128] Naudin S, Viallon V, Hashim D, Freisling H, Jenab M, Weiderpass E, et al. Healthy lifestyle and the risk of pancreatic cancer in the EPIC study. Eur J Epidemiol. 2019, Sep 28. doi: 10.1007/s10654-019-00559-6.

[129] Voelker R. Escalating obesity rates pose health, budget threats. JAMA 2012;308(15):1514.

[130] Calle EE, Kaaks R. Overweight, obesity and cancer: epidemiological evidence and proposed mechanisms. Nat Rev Cancer. 2004;4(8):579-91.

[131] Wang F, Herrington M, Larsson J, Permert J. The relationship between diabetes and pancreatic cancer. Mol Cancer. 2003;2:4. 
1008

1009

1010

1011

1012

1013

1014

1015

1016

1017

1018

1019

1020

1021

1022

1023

1024

1025

1026

1027

1028

1029

1030

1031

1032

1033

1034

1035

1036

1037

1038

1039

1040

1041

1042

1043

1044

1045

1046

1047

1048

1049

1050

[132] Takeda Y, Escribano MJ. Effects of insulin and somatostatin on the growth and the colony formation of two human pancreatic cancer cell lines. J Cancer Res Clin Oncol. 1991;117(5):416-20.

[133] Wang M, Abbruzzese JL, Friess H, Hittelman WN, Evans DB, Abbruzzese MC, et al. DNA adducts in human pancreatic tissues and their potential role in carcinogenesis. Cancer Res. 1998;58(1):38-41.

[134] Mokdad AH, Bowman BA, Ford ES, Vinicor F, Marks JS, Koplan JP. The continuing epidemics of obesity and diabetes in the United States. JAMA. 2001;286(10):1195-200.

[135] Li J, Cao G, Ma Q, Liu H, Li W, Han L. The bidirectional interation between pancreatic cancer and diabetes. World J Surg Oncol. 2012;10:171.

[136] Chari ST, Leibson CL, Rabe KG, Timmons LJ, Ransom J, de Andrade M, et al. Pancreatic cancer-associated diabetes mellitus: prevalence and temporal association with diagnosis of cancer. Gastroenterology. 2008;134(1):95-101.

[137] Krechler T, Jachymova M, Pavlikova M, Vecka M, Zeman M, Krska Z, et al. Polymorphism $-23 \mathrm{HPhI}$ in the promoter of insulin gene and pancreatic cancer: a pilot study. Neoplasma. 2009;56(1):26-32.

[138] Dong X, Li Y, Chang P, Tang H, Hess KR, Abbruzzese JL, et al. Glucose metabolism gene variants modulate the risk of pancreatic cancer. Cancer prevention research. 2011;4(5):75866.

[139] Duell EJ, Lucenteforte E, Olson SH, Bracci PM, Li D, Risch HA, et al. Pancreatitis and pancreatic cancer risk: a pooled analysis in the International Pancreatic Cancer Case-Control Consortium (PanC4). Ann Oncol. 2012;23(11):2964-70.

[140] Davis CD, Uthus EO. DNA methylation, cancer susceptibility, and nutrient interactions. Exp Biol Med. 2004;229(10):988-95.

[141] Zheng W, Lee SA. Well-done meat intake, heterocyclic amine exposure, and cancer risk. Nutr Cancer. 2009;61(4):437-46.

[142] Anderson KE, Sinha R, Kulldorff M, Gross M, Lang NP, Barber C, et al. Meat intake and cooking techniques: associations with pancreatic cancer. Mutat Res. 2002;506-507:225-31.

[143] Distler M, Aust D, Weitz J, Pilarsky C, Grützmann R. Precursor lesions for sporadic pancreatic cancer: PanIN, IPMN, and MCN. Biomed Res Int. 2014;474905.

[144] Patra KC, Bardeesy N, Mizukami Y. Diversity of Precursor Lesions For Pancreatic Cancer: The Genetics and Biology of Intraductal Papillary Mucinous Neoplasm. Clin Transl Gastroenterol 2017;8(4):e86.

[145] Capurso G, Boccia S, Salvia R, Del Chiaro M, Frulloni L, Arcidiacono PG, et al. Risk Factors for Intraductal Papillary Mucinous Neoplasm (IPMN) of the Pancreas: A Multicentre Case - Control Study. Am J Gastroenterol 2013; 108:1003-1009.

[146] Pergolini I, Jäger C, Safak O, Göß R, Novotny A, Ceyhan GO et al. Diabetes and Weight Loss Are Associated With Malignancies in Patients With Intraductal Papillary Mucinous Neoplasms. Clinical Gastroenterology and Hepatology 2020 https://doi.org/10.1016/j.cgh.2020.04.090

[147] Bosetti C, Santucci C, Gallus S, Martinetti M, La Vecchia C. Aspirin and the risk of colorectal and other digestive tract cancers: an updated meta-analysis through 2019. Ann Oncol. 2020; 31(5):558-568 
[148] Zhang Y, Liu L, Fan P, Bauer N, Gladkich J, Ryschich E, et al. Aspirin counteracts cancer stem cell features, desmoplasia and gemcitabine resistance in pancreatic cancer. Oncotarget. 2015; 6(12):9999-10015

[149] Sun J, Li Y, Liu L, Jiang Z, Liu G. Aspirin use and pancreatic cancer risk: A systematic review of observational studies. .Medicine (Baltimore). 2019; 98(51):e18033

[150] Archibugi L, Arcidiacono PG, Capurso G. Statin use is associated to a reduced risk of pancreatic cancer: A meta-analysis. Dig Liver Dis. 2019; 51(1):28-37.

[151] Zhang Y, Liang M, Sun C, Qu G, Shi T, Min Met al.Statin Use and Risk of Pancreatic Cancer: An Updated Meta-analysis of 26 Studies. Pancreas 2019; 48(2):142-150.

[152] Tamburrino D, Crippa S, Partelli S, Archibugi L, Arcidiacono PG, Falconi M et al. Statin use improves survival in patients with pancreatic ductal adenocarcinoma: A meta-analysis. Dig Liver Dis. 2020; 52(4):392-399.

[153] Wang D, Rodriguez EA, Barkin JS, Donath EM, Pakravan AS. Statin Use Shows Increased Overall Survival in Patients Diagnosed With Pancreatic Cancer: A Meta-Analysis. .Pancreas. 2019; 48(4):e22-e23.

[154] Wong WW, Dimitroulakos J, Minden MD, Penn LZ. HMG-CoA reductase inhibitors and the malignant cell: the statin family of drugs as triggers of tumor-specific apoptosis. Leukemia 2002; 16(4):508-19.

[155] Cui X, Xie Y, Chen M, Li J, Liao X, Shen J, et al. Statin use and risk of pancreatic cancer: a meta-analysis. Cancer Causes Control. 2012; 23(7):1099-111

[156] Steinmetz KA, Potter JD. Vegetables, fruit, and cancer prevention: a review. J Am Diet Assoc. 1996;96(10):1027-39.

[157] Tsao AS, Kim ES, Hong WK. Chemoprevention of cancer. CA: a cancer journal for clinicians. 2004;54(3):150-80.

[158] Haugvik SP, Hedenström P, Korsæth E, Valente R, Hayes A, Siuka D, et al. Diabetes, smoking, alcohol use, and family history of cancer as risk factors for pancreatic neuroendocrine tumors: a systematic review and meta-analysis. Neuroendocrinology. 2015;101(2):133-42.

[159] Zhao Z, Yin Z, Pu Z, Zhao Q. Association Between Consumption of Red and Processed Meat and Pancreatic Cancer Risk: A Systematic Review and Meta-analysis. Clin Gastroenterol Hepatol. 2017; 15(4):486-493.

[160] Talamini R, Polesel J, Gallus S, Dal Maso L, Zucchetto A, Negri E, et al.. Tobacco smoking, alcohol consumption and pancreatic cancer risk: a case-control study in Italy. Eur J Cancer. 2010; 46(2):370-6.

[161] McCullough ML, Jacobs EJ, Shah R, Campbell PT, Wang Y, Hartman TJ, et al. Meat consumption and pancreatic cancer risk among men and women in the Cancer Prevention Study-II Nutrition Cohort. Cancer Causes Control. 2018;29(1):125-133.

[162] Ghadirian P, Baillargeon J, Simard A, Perret C. Food habits and pancreatic cancer: a casecontrol study of the Francophone community in Montreal, Canada. Cancer Epidemiol Biomarkers Prev. 1995; 4(8):895-9.

[163] Selenskas S, Teta MJ, Vitale JN. Pancreatic cancer among workers processing synthetic resins. Am J Ind Med. 1995; 28(3):385-98.

[164] Fan X, Alekseyenko AV, Wu J, Peters BA, Jacobs EJ, Gapstur SM et al. Human oral microbiome and prospective risk for pancreatic cancer: a population-based nested casecontrol study. Gut.2018; 67(1):120-127. 

Disease and Risk of Pancreatic Cancer. Pancreas. 2016; 45(1):134-41. 
Table 1: Risk Factors for PaCa

\begin{tabular}{|c|c|c|c|c|c|c|}
\hline Factors & $\begin{array}{l}\text { Number } \\
\text { patients }\end{array}$ & Effect size & CI 95\% & P value & Type of study & Reference \\
\hline \multicolumn{7}{|l|}{ Lifestyle and environmental factors } \\
\hline \multicolumn{7}{|l|}{ Smoking } \\
\hline $\begin{array}{l}\text { Current smokers } \\
\text { Former smokers }\end{array}$ & $2,517,623$ & $\begin{array}{l}\text { HR } 1.56^{\mathrm{a}} \\
\text { HR } 1.15^{\mathrm{a}}\end{array}$ & $\begin{array}{l}1.34-1.83 \\
1.06-1.26\end{array}$ & & Meta-analysis & Ben et al [23] \\
\hline $\begin{array}{l}\geq 30 \text { cigarettes/day } \\
>30 \text { years smoking } \\
>20 \text { years quitting }\end{array}$ & & $\begin{array}{l}\text { RR 2.2 } \\
\text { RR } 1.8^{\mathrm{a}} \\
\operatorname{RR} 0.6^{\mathrm{b}}\end{array}$ & $\begin{array}{l}1.9-2.4 \\
1.6-2.0 \\
0.6-0.7\end{array}$ & & Meta-analysis & Lugo et al. [18] \\
\hline $\begin{array}{l}10 \text { cigarettes/day } \\
10 \text { cigarettes/day } \\
20 \text { cigarettes/day } \\
30 \text { cigarettes/day } \\
40 \text { cigarettes/day }\end{array}$ & 18,006 & $\begin{array}{l}\text { RR } 1.5^{\mathrm{a}} \\
\text { RR } 1.9^{\mathrm{a}} \\
\text { RR } 2.0^{\mathrm{a}} \\
\operatorname{RR} 2.1^{\mathrm{a}} \\
\operatorname{RR} 2.1^{\mathrm{a}}\end{array}$ & $\begin{array}{l}1.4-1.6 \\
1.8-2.0 \\
1.9-2.1 \\
1.9-2.3 \\
1.9-2.3\end{array}$ & $<0.05$ & Meta-analysis & Zou et al. [22] \\
\hline $\begin{array}{l}\text { Alcohol, Smoking, BMI, Physical } \\
\text { activity, Dietary quality }\end{array}$ & 1,057 & $\mathrm{RR} 0.42^{\mathrm{c}}$ & $0.26-0.66$ & $<0.001$ & Cohort & Jiao et al. [19] \\
\hline
\end{tabular}




\begin{tabular}{|c|c|c|c|c|c|c|}
\hline $\begin{array}{l}\text { Ever alcohol use } \\
\text { Heavy alcohol use }\end{array}$ & 827 & $\begin{array}{l}\text { OR } 1.09 \\
\text { OR } 2.72\end{array}$ & $\begin{array}{l}0.64-1.85 \\
1.25-5.91\end{array}$ & $\begin{array}{l}0.75 \\
0.01\end{array}$ & Meta-analysis & $\begin{array}{c}\text { Haugvik et al. } \\
{[158]}\end{array}$ \\
\hline $\begin{array}{l}\text { High alcohol intake ( } \geq 24 \mathrm{~g} / \text { day }) \\
\text { Liquor intake }\end{array}$ & 11,846 & $\begin{array}{l}\text { RR } 1.15^{\mathrm{d}} \\
\text { RR } 1.43^{\mathrm{d}}\end{array}$ & $\begin{array}{l}1.06-1.25 \\
1.17-1.74\end{array}$ & $0.001 /$ & Meta-analysis & Wang et al. [31] \\
\hline $\begin{array}{l}<3 \text { drink/day } \\
>3 \text { drink/day }\end{array}$ & & $\begin{array}{l}\text { RR } 0.92^{\mathrm{e}} \\
\text { RR } 1.22^{\mathrm{e}}\end{array}$ & $\begin{array}{l}0.86-0.97 \\
1.12-1.34\end{array}$ & $\begin{array}{l}0.06 \\
0.266\end{array}$ & Meta-analysis & $\begin{array}{c}\text { Tramacere et al. } \\
{[29]}\end{array}$ \\
\hline $\begin{array}{l}<7 \text { drinks/week } \\
\text { 7-13 drinks/week } \\
\text { 14-20 drinks/week } \\
\text { 21-34 drinks/week } \\
>35 \text { drinks/week }\end{array}$ & 326 & $\begin{array}{l}\text { OR } 1.04 \\
\text { OR } 1.47 \\
\text { OR } 1.50 \\
\text { OR } 2.03 \\
\text { OR } 3.42\end{array}$ & $\begin{array}{l}0.60-1.80 \\
0.83-2.62 \\
0.86-2,62 \\
1.10-3.74 \\
1.79-6.55\end{array}$ & $<0.01$ & Case- Control & $\begin{array}{c}\text { Talamini et al. } \\
{[160]}\end{array}$ \\
\hline $\begin{array}{l}>45 \text { grams of alcohol from liqueur } \\
\text { /day versus none (Men) } \\
>30 \text { grams of alcohol from liqueur } \\
\text { /day versus none (Women) }\end{array}$ & 288 & $\begin{array}{l}\text { OR } 2.23 \\
\text { OR } 1.35\end{array}$ & $\begin{array}{l}1.02-4.87 \\
0.63-2.87\end{array}$ & $\begin{array}{c}0.012 \\
\mathrm{~ns}\end{array}$ & Cohort & $\begin{array}{c}\text { Michaud et al. } \\
\text { [107] }\end{array}$ \\
\hline $\begin{array}{l}\text { Heavy drinkers Men (>60 g/day) } \\
\text { Heavy drinkers Women (>30 g/day) }\end{array}$ & 1,283 & $\begin{array}{l}\text { HR } 1.77^{\mathrm{f}} \\
\operatorname{HR} 0.93^{\mathrm{f}}\end{array}$ & $\begin{array}{l}1.06-2.95 \\
0.47-1.85\end{array}$ & $\begin{array}{c}0.03 \\
\mathrm{~ns}\end{array}$ & Prospective & Naudin et al.[30] \\
\hline
\end{tabular}




\begin{tabular}{|c|c|c|c|c|c|c|}
\hline Processed meat consumption & & $\begin{array}{l}\text { RR } 1.18^{\mathrm{g}} \text { (men) } \\
\text { RR } 0.99^{\mathrm{g}} \text { (women) }\end{array}$ & $\begin{array}{l}1.06-1.31 \\
0.84-1.16\end{array}$ & $\begin{array}{l}0.003 \\
0.88\end{array}$ & Meta-analysis & Zhao et al. [159] \\
\hline Red meat consumption & & $\begin{array}{l}\text { RR } 1.21^{\mathrm{g}} \text { (men) } \\
\text { RR } 1.06^{\mathrm{g}} \text { (women) }\end{array}$ & $\begin{array}{l}1.07-1.37 \\
0.85-1.31\end{array}$ & $\begin{array}{l}0.002 \\
0.61\end{array}$ & Meta-analysis & Zhao et al. [159] \\
\hline Red and processed meat & 1,156 & $\begin{array}{c}\text { HR } 1.32{\text { (men })^{\mathrm{h}}} \\
\text { HR } 0.72 \text { (women) }{ }^{\mathrm{h}}\end{array}$ & $\begin{array}{l}0.90-1.95 \\
0.47-1.10\end{array}$ & 0.01 & $\begin{array}{l}\text { Prospective } \\
\text { cohort }\end{array}$ & $\begin{array}{c}\text { McCullough et al. } \\
{[161]}\end{array}$ \\
\hline Poultry consumption & 1,156 & HR $1.27^{\mathrm{i}}$ & $1.04-1.55$ & 0.01 & $\begin{array}{c}\text { Prospective } \\
\text { cohort }\end{array}$ & $\begin{array}{c}\text { McCullough et al. } \\
{[161]}\end{array}$ \\
\hline Barbecued Meat & 193 & OR 2.19 & $1.4-3.4$ & & Case-control & $\begin{array}{c}\text { Anderson et al. } \\
\text { [142] }\end{array}$ \\
\hline $\begin{array}{l}\text { Salt } \\
\text { Smoked meat } \\
\text { Dehydrated food } \\
\text { Fried food } \\
\text { Refined sugar } \\
\text { Cooking with firewood }\end{array}$ & 179 & $\begin{array}{l}\text { RR } 4.28^{\mathrm{j}} \\
\text { RR } 4.68^{\mathrm{j}} \\
\text { RR } 3.10^{\mathrm{j}} \\
\text { RR } 3.84^{\mathrm{j}} \\
\text { RR } 2.81^{\mathrm{j}} \\
\text { RR } 4.63^{\mathrm{j}}\end{array}$ & $\begin{array}{r}2.20-8.36 \\
2.05-10.69 \\
1.55-6.22 \\
1.74-8.48 \\
0.94-8.45 \\
1.15-16.52\end{array}$ & $<0.01$ & Case-control & $\begin{array}{c}\text { Ghadirian et al. } \\
\text { [162] }\end{array}$ \\
\hline \multicolumn{7}{|l|}{ Toxins } \\
\hline Cadmium & 1,769 & *166 & $98-280$ & 0.059 & Meta-analysis & $\begin{array}{c}\text { Schwartz et al. } \\
{[55]}\end{array}$ \\
\hline
\end{tabular}




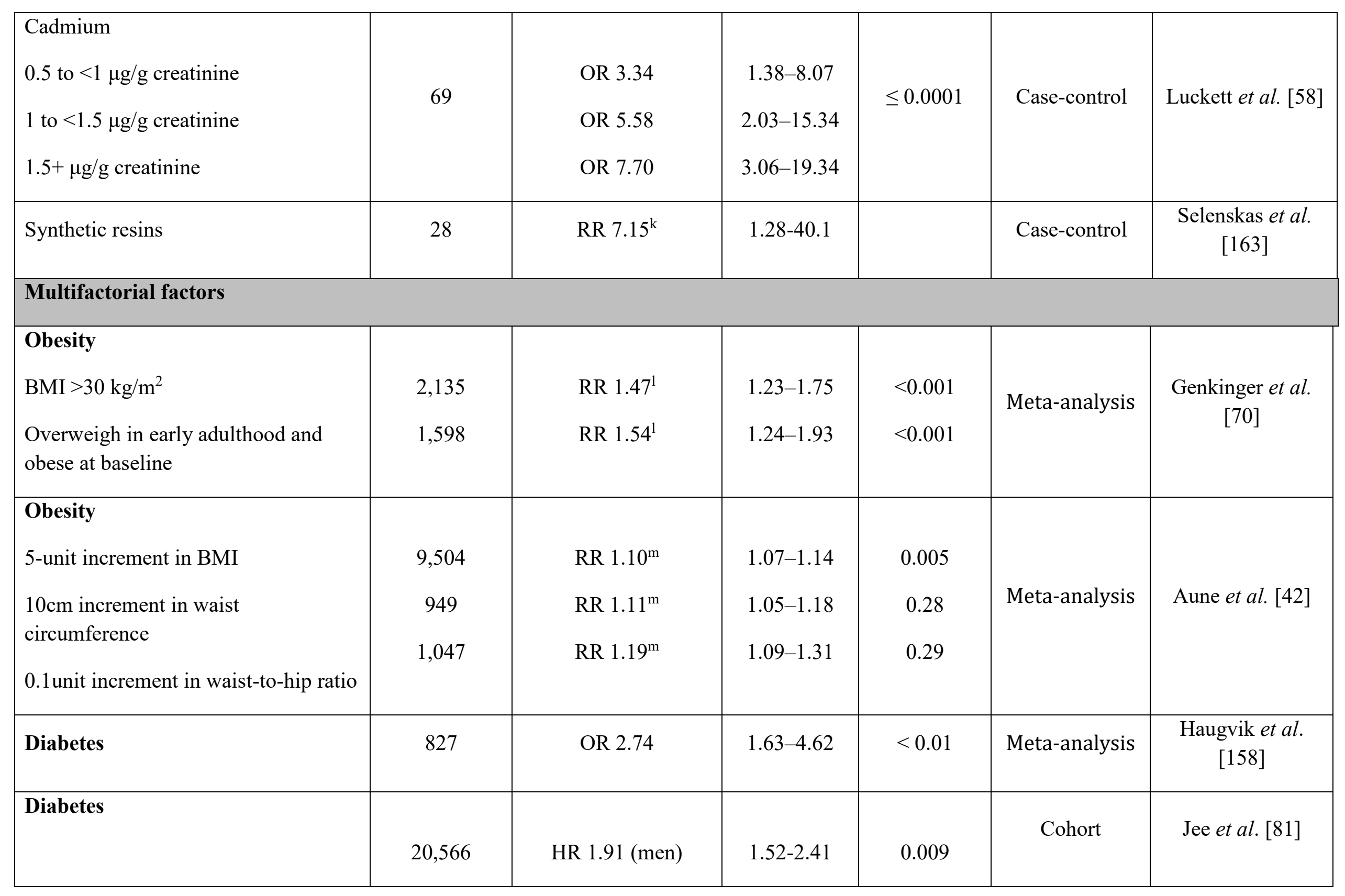




\begin{tabular}{|c|c|c|c|c|c|c|}
\hline $\begin{array}{l}\text { Highest fasting serum glucose }(\geq 140 \\
\mathrm{mg} / \mathrm{dL}) \text { vs lowest level }(<90 \mathrm{mg} / \mathrm{dL})\end{array}$ & 5,907 & HR 2.05 (women) & $1.43-2.93$ & 0.01 & & \\
\hline $\begin{array}{l}\text { Diabetes } \\
\text { Presence of HK2 R844K GA/AA } \\
\text { genotype in diabetic patients }\end{array}$ & 1,654 & OR 3.69 & $2.34-5.82$ & $<0.001$ & Case-control & Dong et al. [138] \\
\hline $\begin{array}{l}\text { Diabetes in patients positive for K-ras } \\
\text { codon } 12 \text { mutations }\end{array}$ & 245 & $\mathrm{AOR}^{\#} 3.4$ & $1.3-8.8$ & & Cohort & Fryzek et al. [84] \\
\hline Infections (H. pylori) & 2,049 & OR 1.06 & $0.74-1.37$ & $<0.001$ & Meta-analysis & Wang et al. [98] \\
\hline $\begin{array}{l}\text { Oral pathogens } \\
\text { Porphyromonas gingivalis } \\
\text { Aggregatibacter } \\
\text { actinomycetemcomitans }\end{array}$ & 361 & $\begin{array}{l}\text { OR } 1.60 \\
\text { OR } 2.20\end{array}$ & $\begin{array}{l}1.15-2.22 \\
1.16-4.18\end{array}$ & 0.0047 & Case control & Fan et al. [164] \\
\hline Periodontal disease & 139,805 & HR $1.55^{\mathrm{n}}$ & $1.02-2.33$ & $<0.001$ & Case control & Chang et al. [165] \\
\hline
\end{tabular}

1100 AOR: adjusted odds ratio; BMI: body mass index; HR: hazard risk; ns: non-significant; OR: odds ratio; RR: relative risk.

1101 Reference category; ${ }^{\mathrm{a}}$ never smokers; ${ }^{\mathrm{b}}$ current smokers; ${ }^{\mathrm{c}}$ lowest combined score; ${ }^{\mathrm{d}}$ lowest alcohol intake level or no alcohol intake; ${ }^{\mathrm{e}}$ non- or

1102 occasional drinkers; ${ }^{\mathrm{f}} 0.1-4.9 \mathrm{~g} /$ day; ${ }^{\mathrm{g}}$ lowest consumption; ${ }^{\mathrm{h}}$ lowest quartile of consumption; ${ }^{\mathrm{i}}$ lowest quintile of consumption; ${ }^{\mathrm{j}}$ never consumed; ${ }^{\mathrm{k}}$ no 1103 exposure; ${ }^{1}$ baseline BMI between $21-22.9 \mathrm{~kg} / \mathrm{m}^{2} ;{ }^{\mathrm{m}}$ no increment; $\mathrm{n}$ no disease.

$1104 *$ Standardized mortality ratio

1105 \# adjusted for cigarette smoking, BMI and diabetes 
Figure 1: Risk factors and potential mechanisms in PaCa development. Summary of lifestyle factors (e.g. high alcohol, fructose and red or processed meat intake), pathological conditions (e.g. obesity, type 2 diabetes, metabolic syndrome and infections), stress and smoking behaviour that may cause DNA damage, interfere with pancreatic physiology or function, induce inflammation and play a role in PaCa development.

1110 NGF: increased nerve growth factor; PPP: pentose phosphate pathway; ROS: reactive oxygen species; VEGF: vascular endothelial growth factor

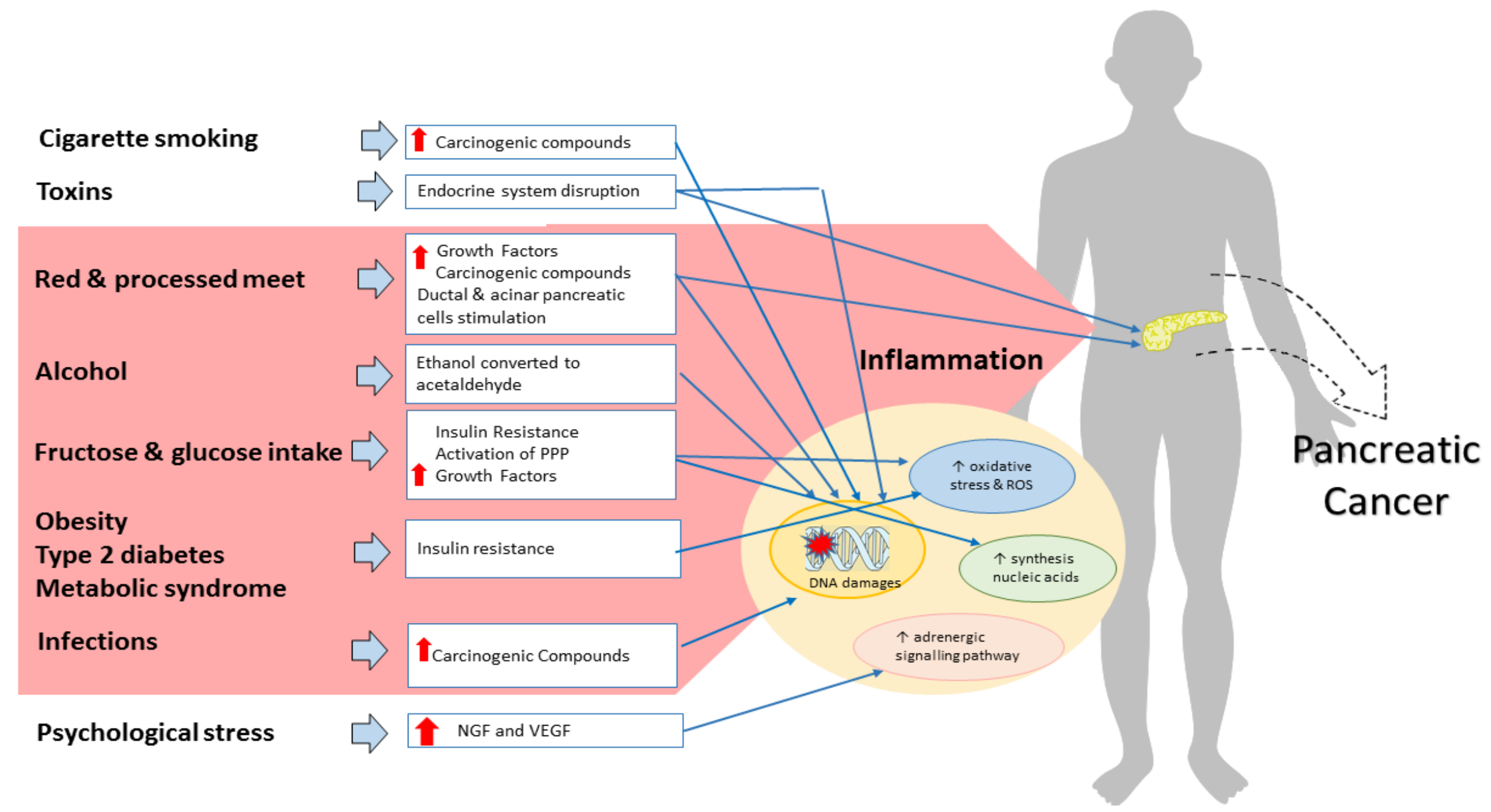

